
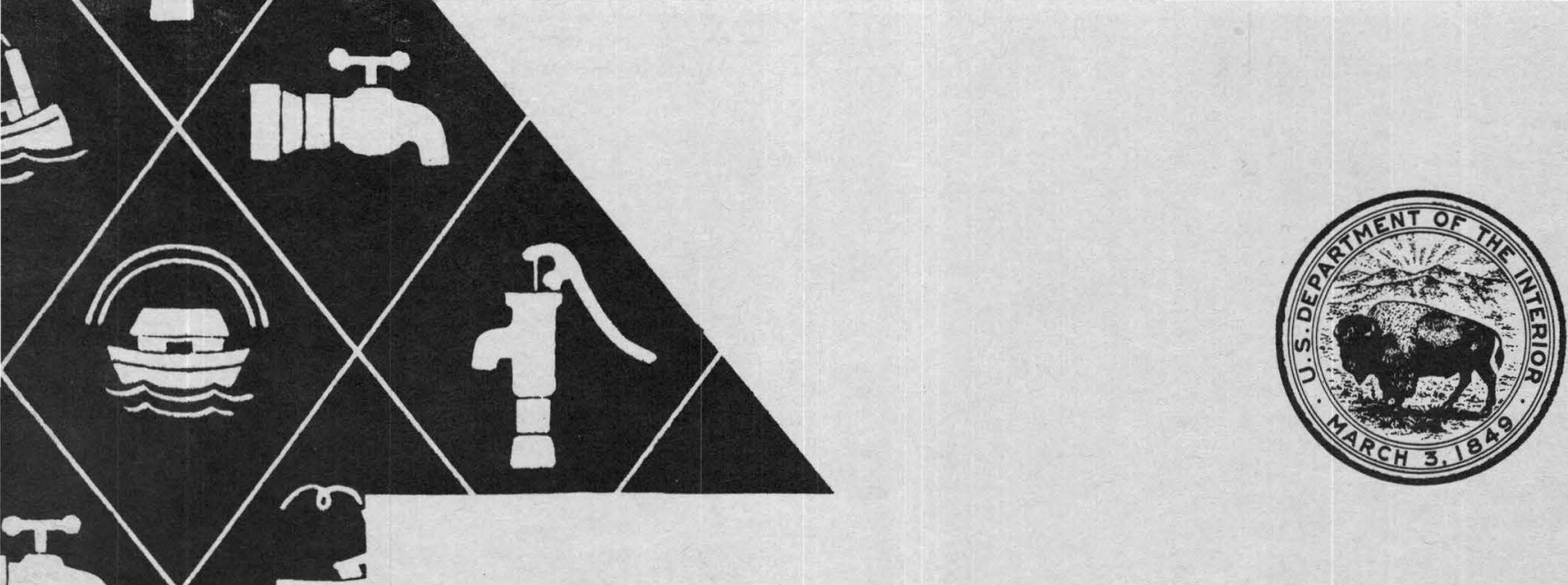

Water-Resources Summary for Southern California, 1959

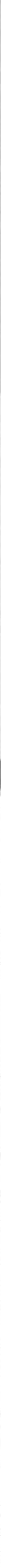





\section{Water-Resources Summary for Southern California, 1959}

By William C. Peterson

父

Geological Survey Circular 429 
United States Department of the Interior FRED A. SEATON, SECRETARY

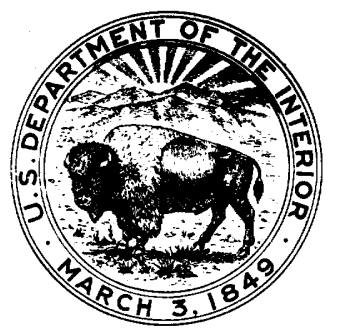

\section{Geological Survey}

THOMAS B. NOLAN, DiReCtOR 


\section{CONTENTS}

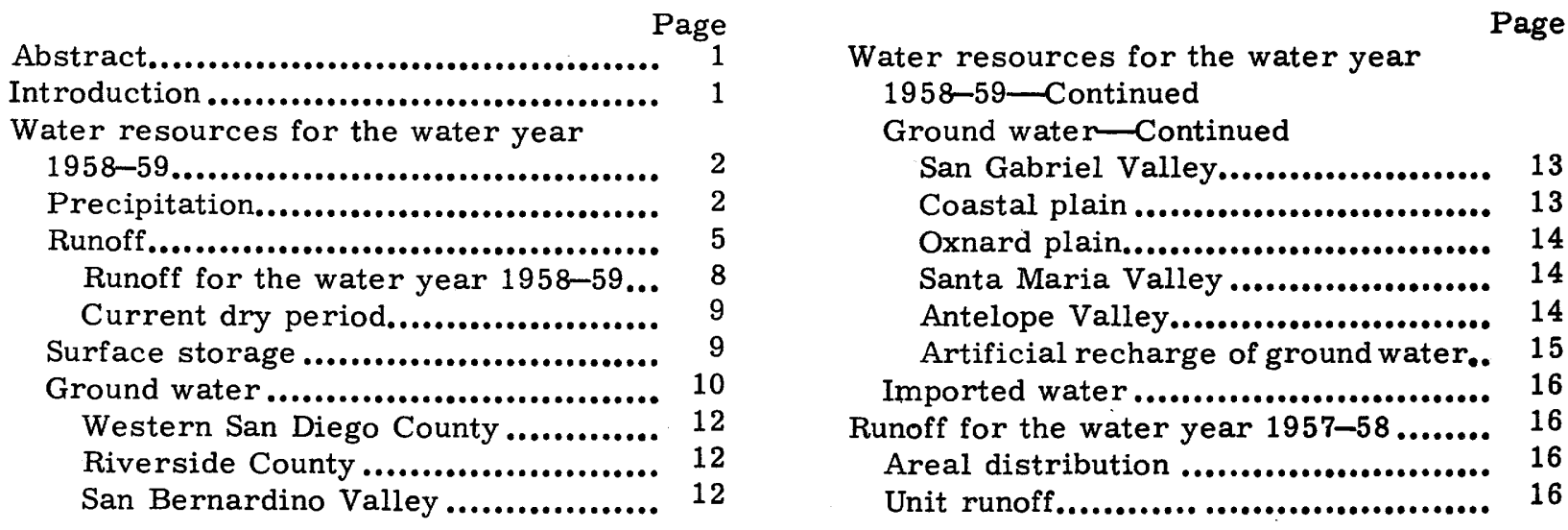

\section{ILLUSTRATIONS}

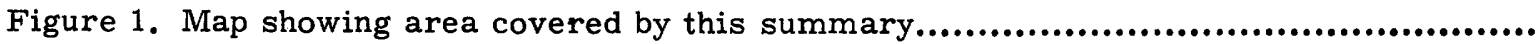

2. Map showing location of selected precipitation stations, gaging stations, and observation wells.

3. Graph showing cumulative departure of annual precipitation from average, 1850-1959.

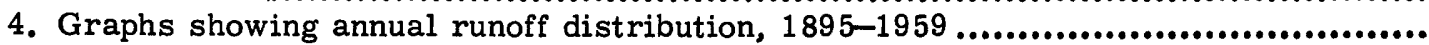

5. Graphs showing mean annual runoff for different periods, $1895-1959 . \ldots . . . . . . . . . . .$.

6. Graphs showing water-level fluctuation at selected observation wells ..................

7. Graph showing water imported into southern California....................................

8. Map showing areal distribution of runoff for the water year $1957-58 . . . \ldots . . . . . . . . . . .$. 6 6 6 


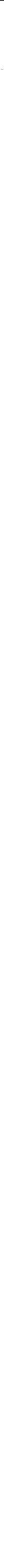




\title{
Water-Resources Summary for Southern California 1959
}

\author{
By William C. Peterson
}

\begin{abstract}
Current water requirements for southern California are more than 2 million acre-feet per year. These requirements are being met by supplementing insufficient local water resources with imported water.

Average annual precipitation ranges from about 2 inches in parts of the desert to about 50 inches in the higher mountains, and there is a great variation in annual precipitation at any one place. The annual variation is not random, but tends to follow a cyclic pattem made up of altemating wet and dry periods. Records of the climatic year (July 1, 1958June 30,1959 ) indicate that the precipitation was 47 percent below average, thus continuing the current dry period which began in 1944 .

Runoff follows the same pattem of wet and dry periods shown by precipitation, but with even greater variability. Runoff for the 1958-59 water year at 15 selected gaging stations ranged from 0.03 to 6.4 inches, with departures from the average annual runoff for the 35-year base period, $1920-55$, ranging from -40 to -97 percent. Average runoff of this group of gaging stations for the 1958-59 water year was 1.45 inches, a departure of -64 percent from the base mean but yet more than twice the average nunoff for the very dry 1950-51 water year. Average annual runoff for the 15-year dry period that began in 1944 ranged from 0.32 to 7.7 inches with an average departure of -34 percent from the base-period mean.
\end{abstract}

Most reservoirs storing natural runoff were only partly full, and some were practically empty. The combined content of 12 representative reservoirs in September 1959 was 33 percent of capacity. Holdover storage, obtained in the wet year 1958, was reduced 9 percent during the 1958-59 water year.

The accelerated trend in ground-water depletion that also began in 1944 continued during the year in the desert areas. Elsewhere, though still reflecting the recharge provided during the very wet 1958 water year, most ground-water levels were again approaching the lowest of record (1957) despite the use of imported water.

The rapid increase in water requirements has accelerated the importation of water from the Colorado River from 20,000 acre-feet in 1944 to 647,000 acre-feet in 1959. During the same period, water imported from the Owens Valley was almost equal to aqueduct capacity; about 345,000 acre-feet was imported from this source during 1959.

Runoff data for the 1957-58 water year from all currently published gaging-station records establish that year as the second relatively wet year in a predominantly dry period that has persisted since October 1944.

\section{INTRODUCTION}

This edition of the water-resources summary for southern California is the 17 th in a series issued annually since June 1944. Its main purpose is to present a brief analysis of those phases of local water supply associated with the work of the Geological Survey in southern California.

The first part of this summary deals with water resources for the water year ending September 30,1959 . It contains a brief analysis of annual precipitation, annual runoff (provisional) at selected gaging stations, water reserves in both surface and underground reservoirs, and imported water.

The second part gives, in detail, runoff for the preceding water year ending September 30,1958 . A period of about a year, beginning at the end of the water year, is usually required to complete computations of daily discharge for all the gaging stations. An additional 6 months to a year is required to process and present the data in published form in the annual Geological Survey WaterSupply Papers. Consequently, this report represents the earliest release of data on the magnitude of runoff for all gaging stations operated in southern California during the water year 1957-58.

Some information presented in this summary was included in previous editions. The repetition is made so that each edition will be complete and independent of the previous editions.

For the purpose of the summary, southern California is considered to be that part of the 
State extending southward from the Arroyo Grande basin, the Tehachapi Mountains, and the Inyo County line to the boundary with Mexico and extending inland from the Pacific Coast to the Colorado River and the Nevada State line. The inland part of this $47,000-$ square-mile area is predominantly desert; consequently, most of the population centers and agricultural areas of the region are concentrated in a long, narrow strip of coastal land. The chief exceptions are parts of Antelope Valley in the Mojave Desert, and the Coachella and Imperial Valleys in the Colorado Desert. The area covered by this summary is shown in figure 1 , and the detailed location of selected installations where hydrologic data are collected is shown in figure 2 .

Because of many desirable climatic and economic factors, the population growth of southern California has been phenomenal, probably the greatest in the United States. A population of about 300,000 in 1900 increased to about 5.7 million by 1950 . About 80 percent of the population increase occurred in the three decades since 1920. Since 1950 the population growth has continued, and it is estimated that the present population of southern California is about 8.8 million.

Such a vast increase in population greatly intensifies the water problems in these arid

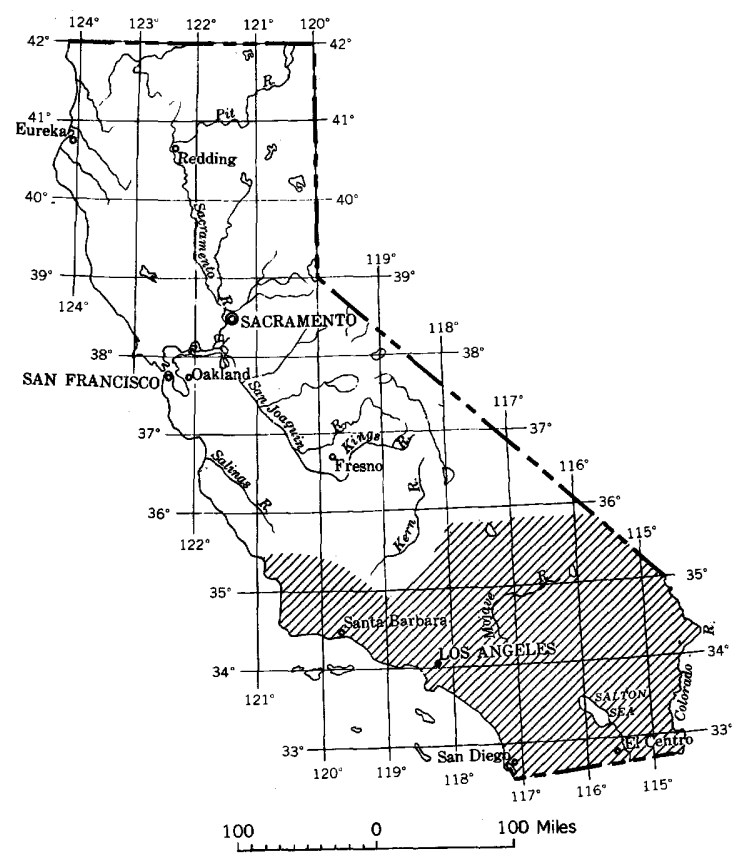

Figure 1. - Map showing area covered by this summary. and semiarid regions of scant water resources. It has been estimated that the water requirements for urban and agricultural uses in the coastal areas were about 1.8 million acre-feet in 1950 and have been steadily increasing at a rate of about 40,000 acre-feet per year. Providing for the increasing water requirements has become a serious problem in many areas. Just how critical the problem is for any community depends largely upon the magnitude of the local ground-water reserves and the ability of the community to import water from outside the basin.

Southern California is forced to obtain its water supply from distant sources because its local water reserves are insufficient. As a result, it pays more for its water than any other area of comparable size in the United States.

\section{WATER RESOURCES FOR THE WATER YEAR 1958-59}

\section{PRECIPITATION}

Very few areas in the United States have ranges in average annual precipitation that are as wide as those observed in southern California. Because of the effect of local physiographic features on the circulation of atmospheric moisutre, the observed average annual precipitation ranges from about 2 inches at Bagdad in the Mojave Desert to more than 50 inches at Morse near Squirrel Inn in the San Bernardino Mountains.

The average annual precipitation of southern California, about 9.5 inches, is only about one-third of the national average of 30 inches. Not more than 2 percent of the area has an average annual precipitation equal to, or larger than, the national average. More than 50 percent of southern California is arid, with an average annual precipitation of 5 inches or less.

Not only is there a great range in average annual precipitation from place to place, but there is often an even greater variation in the annual precipitation at any one place. For example, the annual precipitation at Los Angeles for the climatic year, July 1 to June 30 , has ranged from 5.58 inches in 1958-59 to 38.18 inches in $1883-84$, and ave raged 14.95 


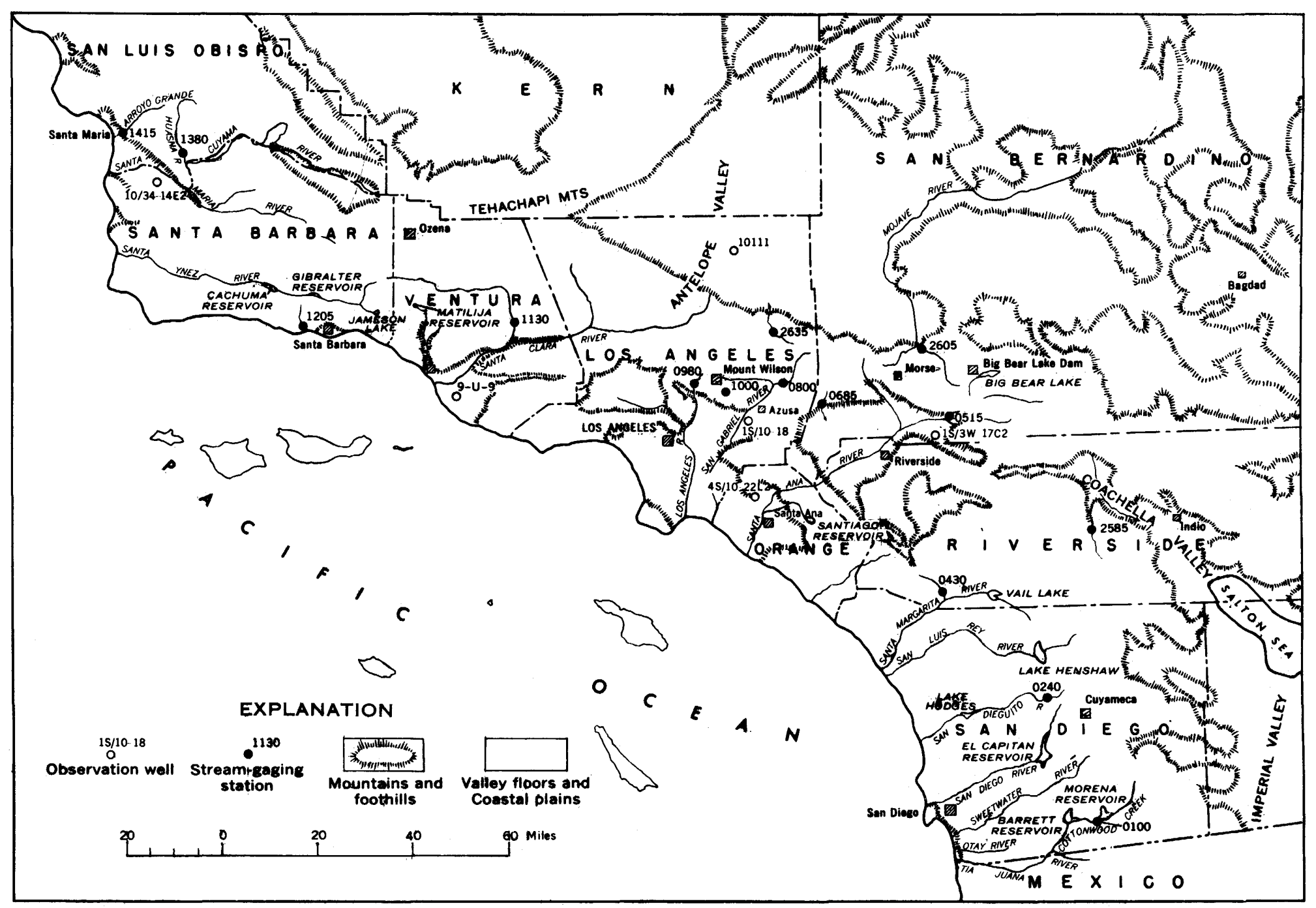




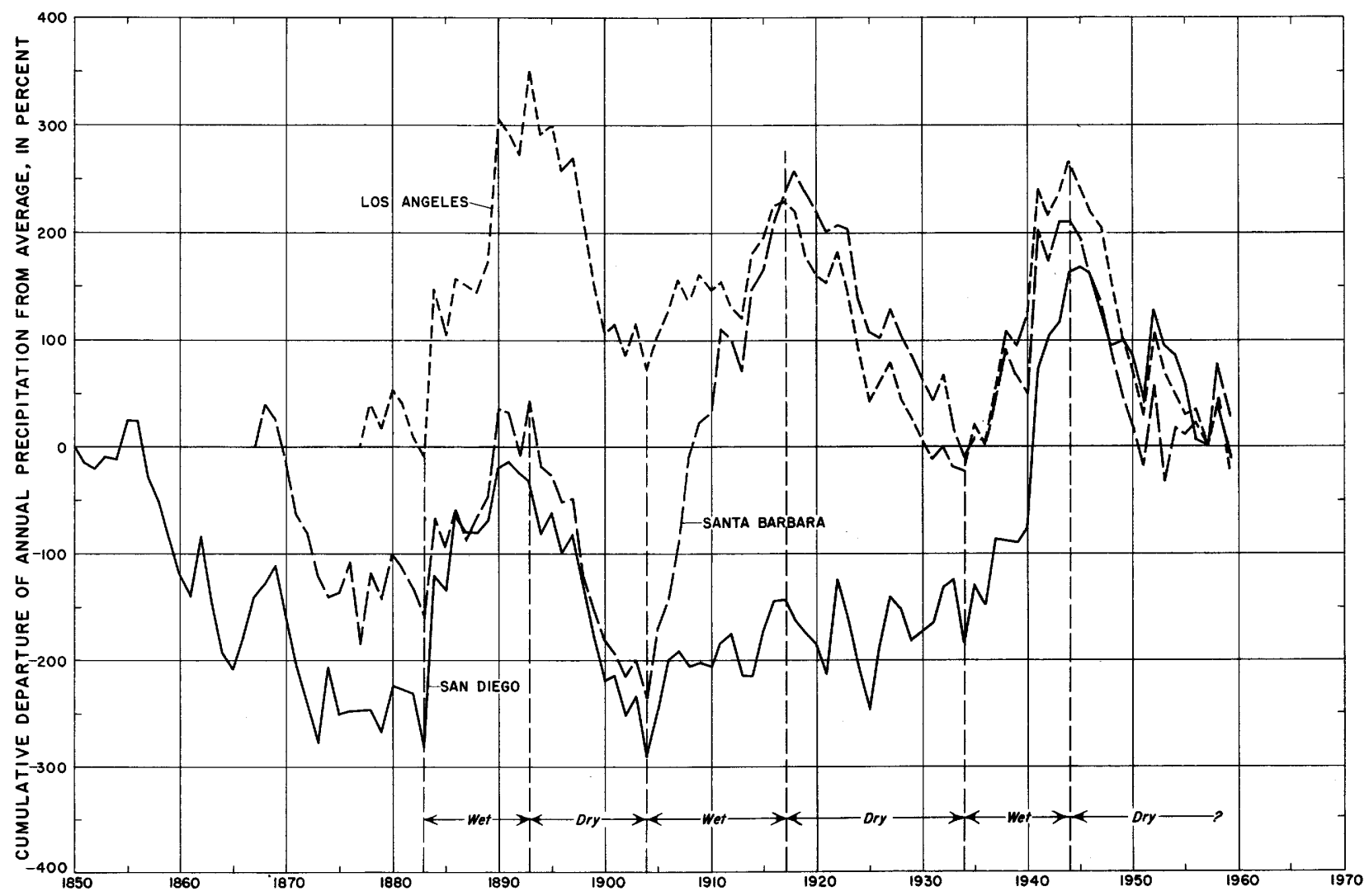

Figure 3. -Graph showing cumulative departure of annual precipitation from average, 1850-1959. Average for each city is based on period of record through 1957 .

inches for the 82-year period of record ending in 1959. At Indio, in the desert of southern California, the annual precipitation has ranged from 0.18 inch in $1922-23$ to 11.50 inches in 1939-40, and has averaged 3.14 inches for an 81 -year period of record ending in 1959.

The variation in annual precipitation is not random, as it occurs in extended sequences of wet and dry years that tend to define an irregular cyclic pattern-a series of wet years alternating with a series of dry years. This distribution in time is most pronounced on the coastal side of the mountains and least defined in the arid desert regions.

Possibly the longest existing record of these alternating wet and dry periods is to be found in the relative widths of annual growth rings in certain types of trees growing in the mountains of southern California. Schulman 1 has been able to measure the annual growth rings in big-cone spruce for the 560-year period 1385-1944. These records indicate a

1 Schulman, Edmund, 1947. Tree-ring hydrology in southern California: Ariz. Univ, Lab. of Tree-ring Research Bull. 4. definite cyclic pattern of wet and dry periods, the length of the dry periods averaging 14.5 years and the length of the wet periods averaging 12.5 years, making an average cyclic period of 27 years. Not all the individual, years within a wet period are wet, but the wet years predominate; conversely, not all the individual years within a dry period are.dry, but the dry years predominate.

One of the methods used for determining wet and dry periods is that of plotting the cumulative departure of annual precipitation from the average annual. Figure 3 shows the percentage of cumulative departure of annual precipitation at Santa Barbara, Los Angeles, and San Diego from the average annual precipitation. Each of the three average annual values is for the period of record up to and including the climatic year 1956-57. Upward trends on this graph represent wet periods and downward trends represent dry periods.

The observed precipitation for the climatic year July 1, 1958, to June 30,1959 , at the 
stations in Santa Barbara, Los Angeles, and San Diego is given in table 1, together with that at 7 other selected stations that measure precipitation on the major physiographic features of the region. Many of the longest and most complete records in the region have been collected at these stations, and they are intended to serve as general indices of precipitation throughout southern California.

During the year 1958-59, the 15th year of a predominantly dry period that began in 1944 , the precipitation at all 10 stations was considerably below the average for the period of record. In fact, precipitation at Los Angeles and Mount Wilson was the lowest of record. Riverside received the second lowest, and Cuyamaca and Indio received the third lowest precipitation of record.

The average departure for this group of stations was -47 percent, about 4 percent. more than the average departure for the same group of stations for the very dry year 1951 .

\section{RUNOFF}

The precipitation, after satisfying the soilmoisture deficiencies in the root zone of the native vegetation in the mountains and foothills and of the agricultural crops in the valley floors, recharges the ground-water reservoirs or drains into the stream channels as runoff. The part of the precipitation which becomes runoff follows the same cyclic pattern as that shown for the total precipitation plotted in figure 3. However, the cyclic pattern defined by runoff is often more pronounced because the annual runoff may represent only a very small part of annual precipitation. For example, the annual runoff for San Gabriel River basin near Azusa has ranged from as little as 0.86 inch for the water year ending September 30, 1899, to as much as 36.4 inches for the water year ending September 30,1922 , with an average of 9.8 inches for a 64-year period of record.

This range in annual runoff, together with the sequence of wet and dry periods, is shown in figure 4 for the gaging station on the San Gabriel River near Azusa and the gaging station on Santa Ana River near Mentone. Records for both stations reflect the runoff from rugged mountain basins within the Angeles and San Bernardino National Forests, and the runoff at these two stations is assumed to be typical of the mountain runoff in those areas where the basinwide ave rage annual precipitation ranges from 30 to 40 inches. Both records show the same cyclic patterns as those of the annual precipitation. To accentuate this distribution, the graphs delineate the generally accepted division of wet and dry periods for the region and the crosshatched pattern shows the average annual runoff for each of these periods.

It is evident from an inspection of figure 5 that both records contain 3 dry and 2 wet periods, and consequently each mean for the period of record tends to be biased by the greater number of dry periods. For San

Table 1.-Precipitation for the climatic year July 1, 1958 to June 30,1959, and the average annual precipitation for the dry period $1944-59$ at selected precipitation stations

\begin{tabular}{|c|c|c|c|c|c|c|}
\hline \multirow[b]{2}{*}{ Physiographic type and station } & \multicolumn{2}{|c|}{ Period of record } & \multicolumn{2}{|c|}{ Precipitation for $1958-59$} & \multicolumn{2}{|c|}{$\begin{array}{l}\text { Average annual precipitation } \\
\text { for } \cdot 194 \overline{4-59} \text { dry period }\end{array}$} \\
\hline & $\begin{array}{l}\text { Length } \\
\text { (years) }\end{array}$ & $\begin{array}{c}\text { Average } \\
\text { annual } \\
\text { precipitation } \\
\text { (inches) }\end{array}$ & Inches & $\begin{array}{c}\text { Departure } \\
\text { from } \\
\text { average } \\
\text { (percent) }\end{array}$ & Inches & $\begin{array}{c}\text { Departure } \\
\text { from } \\
\text { average } \\
\text { (percent) }\end{array}$ \\
\hline \multicolumn{7}{|l|}{ Coastal and plain: } \\
\hline Valley: Riverside fire station $3 . . . . . . . . .$. & 78 & 11.07 & 4.33 & -61 & 9.13 & -18 \\
\hline Mountain: & & & & & & \\
\hline
\end{tabular}




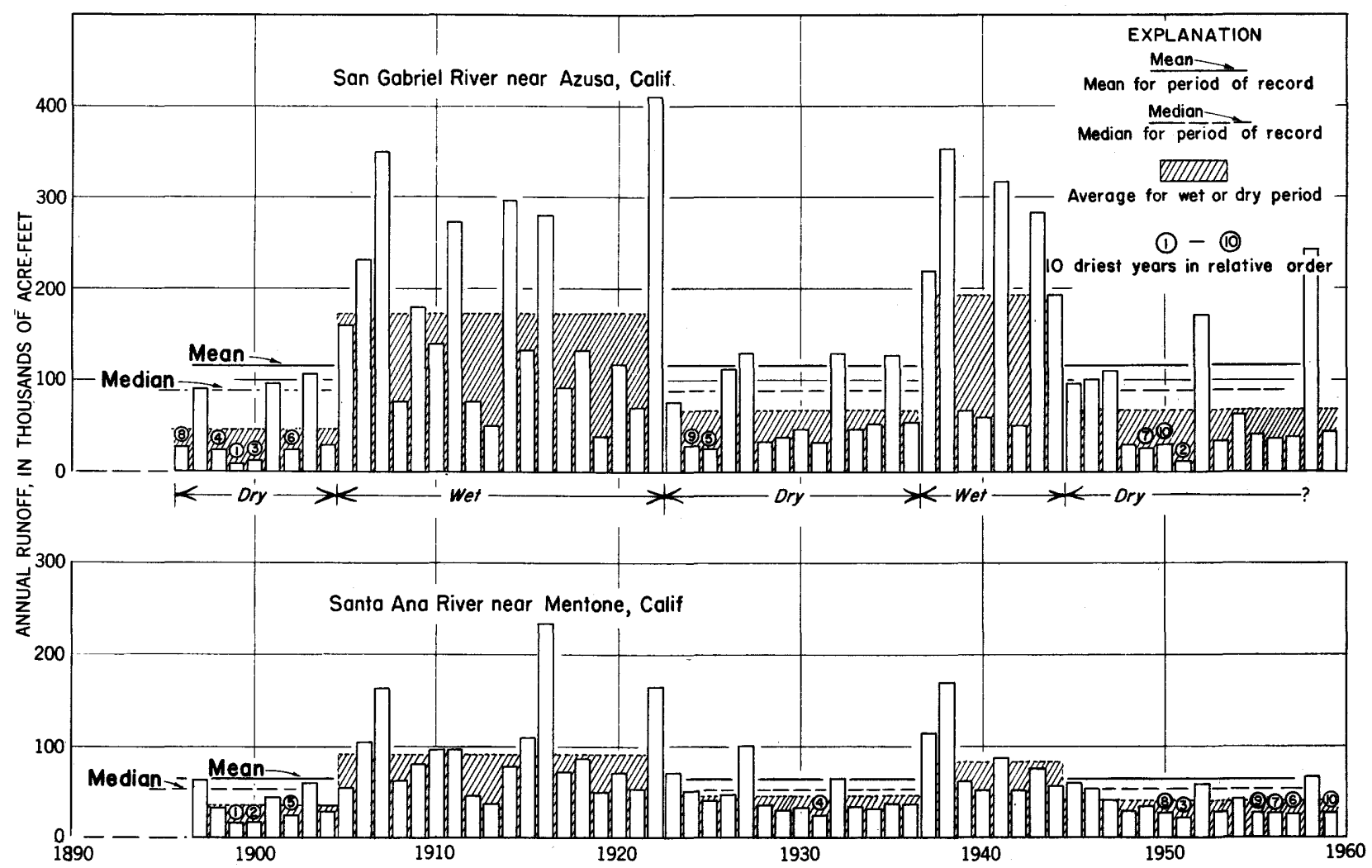

Figure 4. -Graphs showing annual runoff distribution for the gaging stations on San Gabriel River near Azusa and on Santa Ana River near Mentone, 1895-1959.

Gabriel River near Azusa, the least biased records are those for the 49-year period 1895-1944, and for the 55-year period 190459 because each contains 2 wet and 2 dry periods. For Santa Ana River near Mentone, the least biased records are those for the 47year period 1896-1943 and for the 54-year period 1905-59. As there are but few gaging stations in southern California where records are long enough to include 2 wet and 2 , dry periods, it is necessary to consider the use of shorter periods, each containing a single wet and dry sequence. The beginning and the end of each period, together with the mean annual runoff for each period, are shown on figure 5 .

The obvious variation in the data for shorter periods suggests that the long-term mean can not probably be used as a direct measure of dependable runoff for any randomly selected period. Consequently, the long-term mean annual runoff becomes merely an indirect measure of the relative runoff among basins rather than a measure of runoff that is usable or available during extended critical periods.
Despite the inadequacy of the long-term mean for use in reference to most water problems in southern California, the use of mean values as a measure of central tendency is desirable for convenience. Furthermore, mean values based on a common time period (and designated base means) are more useful for direct comparison between basins than are long-term means based on time periods of different length. Admittedly, selection of a common time period must be arbitrary because of regional differences in the beginning and end of wet and dry periods and because the length of these periods is not clearly defined. But, aside from this deficiency, properly interpreted base means have considerable significance in many parts of southern California.

For the water-resources summary, the 30year period beginning October 1920 and ending September 1950 was initially selected for a base period and was used through the 1956 edition of the summary (U.S. Geol. Survey Circ. 399). October 1920 was chosen as the beginning date of the base period in order to 


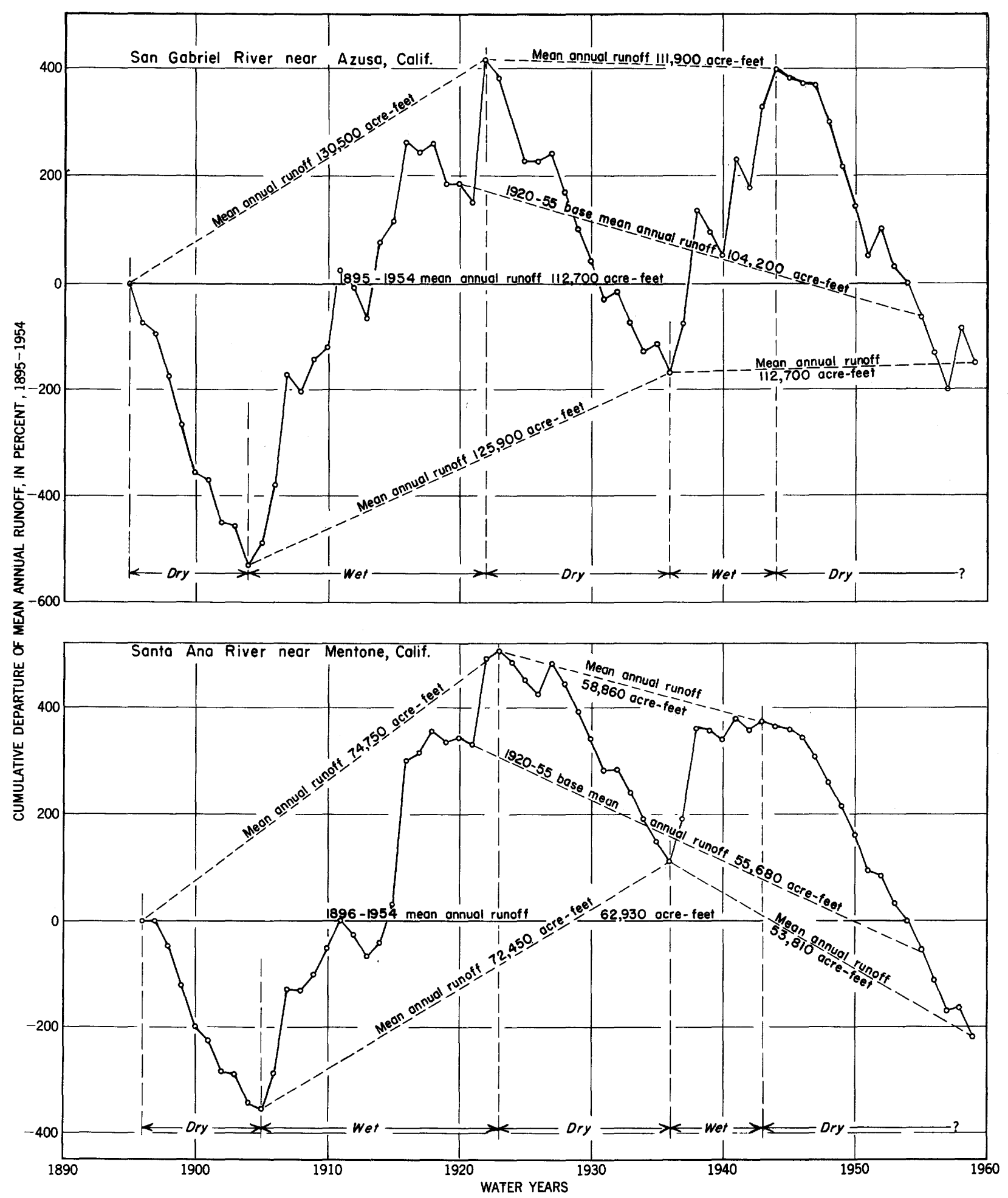

Figure 5. -Graphs showing mean annual runoff for different periods for the gaging stations on San Gabriel River near Azusa and on Santa Ana River near Mentone, 1895-1959. 
conform closely to that of the standard period October 1920 to September 1945, which is used as an index in the "Water Resources Review" of the U.S. Geological Survey and the Canadian Water Resources Branch. Many records of runoff that began later than October 1920 , but which could be extended back to that date with little loss of accuracy, are included in the runoff data for the base period.

For this edition of the summary, as with the preceding editions (U.S. Geol. Survey Circ. 404, 416), the 35-year period from October 1920 to September 1955 is used for computing base means. The base means for the 35-year period are a few percent lower than are those for the 30-year period, which should be borne in mind when comparing percentage departures in this edition of the summary with those in U.S. Geological Survey Circular 399 and earlier editions.

\section{RUNOFF FOR THE WATER YEAR 1958-59}

Runoff for the water year 1958-59 at the 15 gaging stations shown on figure 2 is briefly summarized in table 2 and compared with the average annual runoff for the 35-year base period 1920-55. The purpose of table 2 is to provide a general index of the surface runoff throughout southern California for the water year ending September 30, 1959. Typical of the region is the wide range of the 1958-59 runoff, 0.03 to 6.4 inches, which is due largely to the areal distribution of precipitation.

The departure of the 1958-59 runoff from the 35-year base mean reflects the relatively dry year prevalent in all parts of the southern California. The average runoff for the 1958-59 water year was 1.45 inches, or about 36 percent of the mean annual runoff for the base period, over the 1,464 square miles of

Table 2.-Runoff for the water year 1958-59 and average annual runoff for the dry period 1944-59 at selected gaging stations

\begin{tabular}{|c|c|c|c|c|c|c|c|c|}
\hline \multirow[b]{2}{*}{$\begin{array}{c}\text { Station and reference } \\
\text { number on figure } 2 .\end{array}$} & \multirow[b]{2}{*}{$\begin{array}{c}\text { Drain- } \\
\text { age } \\
\text { (square } \\
\text { miles) }\end{array}$} & \multirow[b]{2}{*}{$\begin{array}{l}1920-55 \\
\text { base-mean } \\
\text { annual } \\
\text { runoff } \\
\text { (acre- } \\
\text { feet) }\end{array}$} & \multicolumn{3}{|c|}{ 1958-59 runoff } & \multicolumn{3}{|c|}{$\begin{array}{l}\text { Average annual runoff } \\
\text { for } 1944-59 \text { dry period }\end{array}$} \\
\hline & & & $\begin{array}{l}\text { Acre- } \\
\text { feet }\end{array}$ & Inches & $\begin{array}{l}\text { Departure } \\
\text { from } \\
\text { base mean } \\
\text { annual } \\
\text { runoff } \\
\text { (percent) }\end{array}$ & $\begin{array}{l}\text { Acre- } \\
\text { feet }\end{array}$ & Inches & $\begin{array}{l}\text { Departure } \\
\text { from } \\
\text { base mean } \\
\text { annual } \\
\text { runoff } \\
\text { (percent) }\end{array}$ \\
\hline \multicolumn{9}{|c|}{ Pacific slope basins } \\
\hline \multicolumn{9}{|c|}{ The Great Basin } \\
\hline $\begin{array}{l}\text { Palm Canyon Creek near } \\
\text { Palm Springs (2585)....... } \\
\text { Deep Creek near } \\
\text { Hesperia (2605)............. } \\
\text { Big Rock Creek near } \\
\text { Valyermo (2635)............. } \\
\end{array}$ & $\begin{array}{l}94.0 \\
137 \\
23.0\end{array}$ & $\begin{array}{r}4,390 \\
44,270 \\
12,100\end{array}$ & $\begin{array}{r}170 \\
13,650 \\
5,190\end{array}$ & $\begin{array}{l}1.9 \\
4.2\end{array}$ & $\begin{array}{l}-69 \\
-57\end{array}$ & $\begin{array}{r}1,590 \\
30,510 \\
8,620\end{array}$ & 4.3 & $\begin{array}{l}-64 \\
-31 \\
-29\end{array}$ \\
\hline
\end{tabular}


area drained by streams given in table 2 . This runoff is about equal to the average runoff during the 1956-57 water year, and more than twice the average runoff ( 0.62 inches) for this group of basins during the very dry year 1950-51.

\section{CURRENT DRY PERIOD}

The annual runoff distribution shown in figure 4 indicates that the water year ending September 30, 1959, was among the driest years of record. Furthermore, this was the 15 th dry year in a predominantly dry period that has persisted since October 1944 and that may not end for some time. Tree-growth studies by Schulman ${ }^{2}$ suggest that dry periods may have persisted for more than 40 years in southern California.

A measure of the relative severity of the dry periods of record is obtained by numbering the 10 driest years, for each of the 2 stations shown in figure 4 , in the order of their dryness. Of these 20 driest years for both stations 9 occurred in the current dry period, 8 occurred in the very dry 9-year period ending September 30, 1904, and only 3 occurred in the 14-year period ending September $30,1936$.

The average annual runoff for the current dry period and its departure from the mean for the base period is included in table 2. For most of the stations, the influence of the 1958-59 runoff on the average annual runoff for the 1944-59 dry period has increased the departure from the 35-year mean. The average departure during the current 15-year dry period for the basins listed is -34 percent in contrast with a departure of -32 percent for the 14-year dry period 1944-58.

\section{SURFACE STORAGE}

Currently there is about 2.2 million acrefeet of surface storage capacity in southern California for municipal, domestic, and irrigational uses. Most of this storage capacity has been obtained by building dams across mountain stream channels. However, because of many adverse topographic features, such as steepness of the stream channels and narrowness of the canyons, construction costs

\footnotetext{
${ }^{2}$ See footnote on page 4
}

are high and reservoir capacities are small. Of 154 reservoirs, only 7 have a capacity in excess of 100,000 acre-feet. Because of their relatively small capacity, it is impossible for many reservoirs to store all the excessive flood runoff occurring during wet periods for use in the following dry periods. Furthermore, some of these reservoirs were not built to store local flood runoff but rather to store and distribute imported water from the Owens Valley and the Colorado River.

An additional storage capacity of more than 460,000 acre-feet has been obtained by the use of reservoirs constructed to provide flood control in the valley floors. Although these flood-control reservoirs are primarily for retarding the flood runoff, a certain amount of water is conserved because provision is made, when possible, to recharge groundwater basins by controlling the release of flood water.

Data on the operation of 12 reservoirs during the current dry period are given in table 3 . These reservoirs, built to store water for domestic, municipal, or irrigational uses, have a combined capacity of about 37 percent of the present total reservoir capacity in southern California. Except for a small amount of water from the Colorado River delivered to Lake Hodges and Santiago Reservoir, the only source of inflow to each reservoir during 1959 was from local runoff.

Morena and Barrett Reservoirs in the Tia Juana River basin are the southernmost of these 12 reservoirs. At the end of the 1958 water year, which was relatively dry in that area, both reservoirs were almost empty. At the end of the very dry 1959 water year the reservoirs were still almost empty. Farther north, however, at Cachuma Reservoir, the storage on September 30, 1958, was just below spillway level owing to above-average runoff during the 1958 water year, which was relatively wet in that area. At the end of the dry 1959 water year the storage was 91 percent of capacity, reflecting necessary use of the holdover storage of the reservoir. Morena and Barrett Reservoirs, with a comparable storage ratio, have not been able to attain such a degree of storage since 1944. Storage ratio, which is defined as the ratio of usable capacity to average annual inflow, is shown in table 3. It is expressed in years and is the time required, assuming average inflow, to 
Table 3.- Storage in selected surface reservoirs

\begin{tabular}{|c|c|c|c|c|c|c|c|c|c|c|c|}
\hline \multirow[b]{2}{*}{ Reservoir } & \multirow{2}{*}{$\begin{array}{c}\text { Average } \\
\text { annual } \\
\text { inflow } \\
1920-55 \\
(\text { acre-feet) }\end{array}$} & \multirow{2}{*}{$\begin{array}{l}\text { Present } \\
\text { capacity } \\
\text { at spill- } \\
\text { way level } \\
\text { (acre-feet) }\end{array}$} & \multirow{2}{*}{$\begin{array}{c}\text { Storage } \\
\text { ratio } \\
\text { (years) }\end{array}$} & \multicolumn{4}{|c|}{ Storage } & \multirow{2}{*}{$\begin{array}{c}\text { Change } \\
\text { in } \\
\text { storage } \\
1958-59 \\
\text { (acre- } \\
\text { feet) }\end{array}$} & \multicolumn{2}{|c|}{$\begin{array}{c}\text { Storage on } \\
\text { Sept. } 30,1944\end{array}$} & \multirow{2}{*}{$\begin{array}{l}\text { Change in } \\
\text { storage } \\
\text { 1944-59 } \\
\text { (acre-feet) }\end{array}$} \\
\hline & & & & \multicolumn{2}{|c|}{ Sept. 30,1958} & \multicolumn{2}{|c|}{ Sept. 30,1959} & & Acro-feet & Percent & \\
\hline 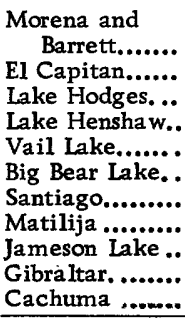 & $\begin{array}{r}24,800 \\
38,600 \\
33,280 \\
24,410 \\
9,810 \\
\ldots \ldots \ldots \ldots \\
11,220 \\
20,910 \\
3,840 \\
30,540 \\
60,700 \\
\end{array}$ & $\begin{array}{r}94,970 \\
112,810 \\
33,550 \\
194,300 \\
49,370 \\
72,200 \\
25,000 \\
7,020 \\
6,760 \\
14,780 \\
204,900 \\
\end{array}$ & $\begin{array}{c}3.8 \\
2.9 \\
1.0 \\
8.0 \\
5.0 \\
\ldots . . .0 \\
2.2 \\
.34 \\
1.8 \\
.48 \\
3.4\end{array}$ & $\begin{array}{r}1,960 \\
43,560 \\
7,000 \\
20,400 \\
6,860 \\
21,290 \\
19,900 \\
7,000 \\
6,160 \\
13,220 \\
196,890\end{array}$ & $\begin{array}{r}2.1 \\
39 \\
21 \\
10 \\
14 \\
29 \\
80 \\
100 \\
91 \\
89 \\
96\end{array}$ & $\begin{array}{r}1,910 \\
22,880 \\
12,480 \\
22,140 \\
3,140 \\
13,250 \\
10,230 \\
6,090 \\
4,830 \\
9,490 \\
187,180\end{array}$ & $\begin{array}{c}2.0 \\
20 \\
7.4 \\
2.1 \\
6.4 \\
18 \\
41 \\
87 \\
86 \\
64 \\
91\end{array}$ & $\begin{array}{r}-50 \\
-20,680 \\
-4,520 \\
-16,260 \\
-3,720 \\
-8,040 \\
-9,670 \\
-910 \\
-1,330 \\
-3,730 \\
-9,710 \\
\end{array}$ & $\begin{array}{r}89,900 \\
79,700 \\
31,100 \\
144,000 \\
\ldots \ldots \ldots \ldots . \ldots \\
47,600 \\
20,400 \\
\ldots \ldots \ldots . \ldots . \\
6,050 \\
6,120 \\
\ldots \ldots \ldots \ldots \ldots . . . .\end{array}$ & 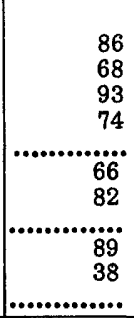 & $\begin{array}{r}-87,990 \\
-56,820 \\
-28,620 \\
-139,860 \\
\ldots \ldots \ldots \ldots \ldots \\
-34,350 \\
-10,170 \\
\ldots \ldots \ldots \ldots \\
-1,220 \\
+3,370 \\
\ldots \ldots \ldots \ldots . . .\end{array}$ \\
\hline
\end{tabular}

1 Mostly Colorado River water.

2. Approximate.

3 Includes estimate for Big Bear Lake.

impound a volume of water equal to the usable capacity of the reservoir.

\section{GROUND WATER}

Over a large part of southern California, the most readily available and best distributed water reserve is the ground water stored in the deep alluvial deposits of the valley floors. A major part of the water supply of the region has been and still is pumped from these sources. The magnitude of these water reserves is difficult to measure; however, it has been estimated by Eckis and Gross ${ }^{3}$ to be about 7.5 million acre-feet in the alluvial deposits in the basins of the Los Angeles, San Gabriel, and Santa Ana Rivers in a zone 100 feet thick extending from 50 feet above to 50 feet below the water levels of January 1933.

Rapid industrial and urban growth has overtaxed these local ground-water reserves. Consequently, the current rate of extraction generally exceeds the average rate of recharge, creating an overdraft. Currently, most ground-water basins in southern California now have, or are threatened by, overdrafts.

The usefulness of a ground-water reservoir, like a surface-water reservoir, is dependent upon its size, the magnitude of the annual increments of recharge, and the annual rate of withdrawal. Also, like a surface-water

'Eckis, Rollin, and Gross, P. L. K., South Coastal Basin Investigation, geology and ground-water storage capacity of valley fill: California Dept, Public Works, Div. Water Resources Bull. $45,273 \mathrm{p}$. reservoir, the ground-water reservoir must capture water in the wet periods and store it to meet the needs of the following dry periods.

The valleys of southern California contain many ground-water basins, a large part of them having complex geologic and hydrologic features. Changes in water levels differ considerably from basin to basin, depending upon the relation between natural recharge and pumping draft. Consequently, it has been necessary to confine the detailed analysis of the fluctuation in water level to the few observation wells indicated on figure 2.

The changes in water level in six selected observation wells for their period of record are shown in figure 6. The arbitrary division into wet and dry periods is based on figure 5 . A light dashed line indicates the rate of decline based chiefly on the years having the least precipitation during each dry period. Assuming that ground-water recharge during all dry periods is small and of about the same magnitude, and increase in the rate of decline becomes a measure of the increase in groundwater withdrawals.

At the end of the 1958 water year, the water levels generally reflected the above-average precipitation for much of the region and the continued use of either imported water or stored storm runoff for artificial recharge of ground-water basins. At the end of the very dry 1959 water year almost all water levels were approaching, and in places falling below, the record low levels of the fall of 1957 . This 


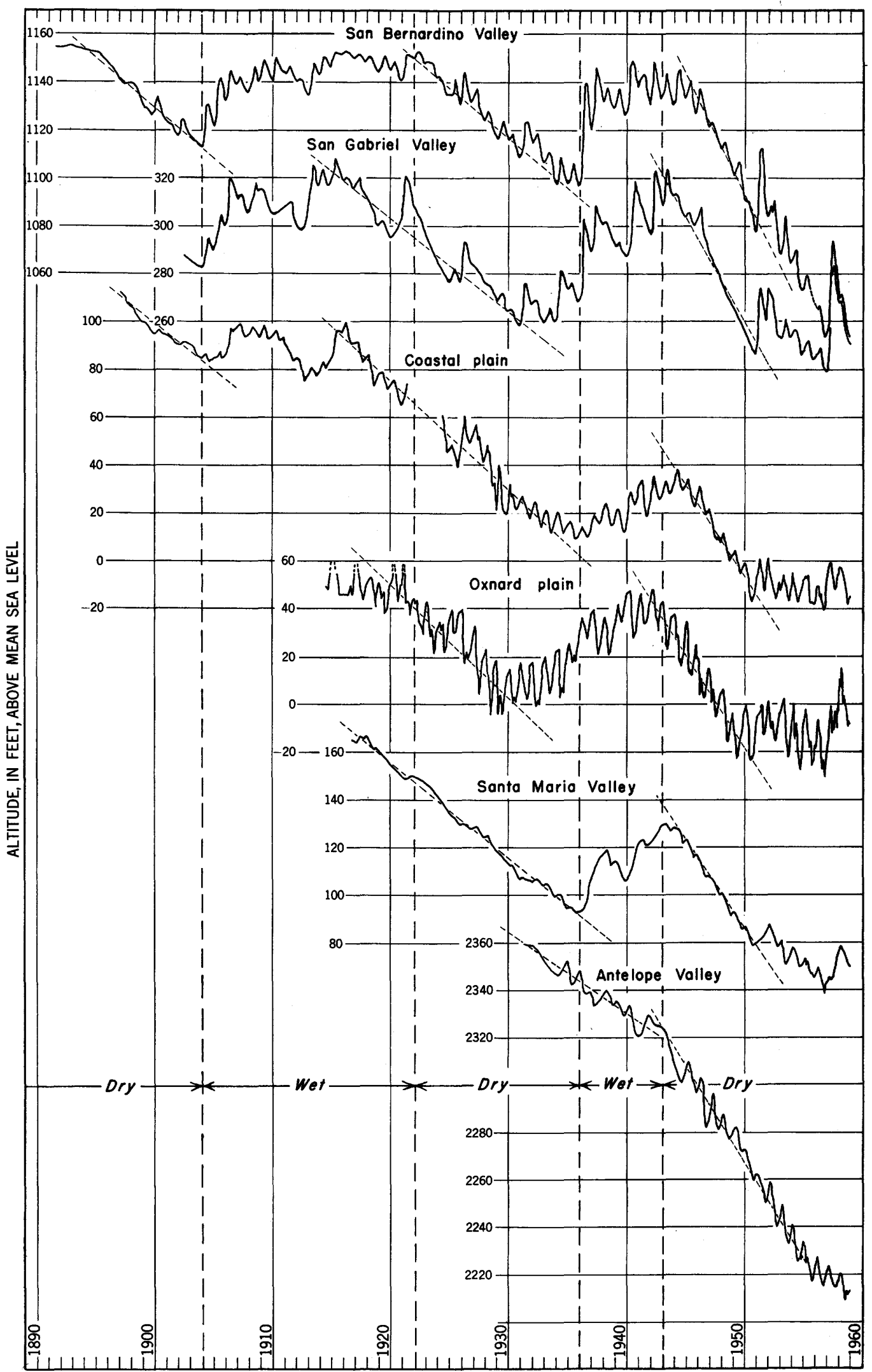

Figure 6. -Graph showing water-level fluctuation at selected observation wells. 
decline in ground-water level, despite the continued use of imported water, reflects the continued increase in regional water requirements and the excess of withdrawals over the small increments of recharge during the preceding 15-year dry period.

\section{WESTERN SAN DIEGO COUNTY}

Ground-water levels in most of the coastal alluvial valleys of western San Diego County declined during the 1959 water year, resuming the downward trend which, since 1940, had brought many wells to the lowest level of the entire period of record. At the present time, areas of known or threatened sea-water encroachment exist in the basins of the Tia Juana, Otay, San Diego, and San Luis Rey Rivers.

\section{RIVERSIDE COUNTY}

Ground-water levels in the arid and semiarid San Jacinto basin have declined steadily since the first observations were made in 1904. The Riverside County Flood Control and Water Conservation District estimated that the water level in observation well $4 \mathrm{~S} / 1 \mathrm{~W}-35 \mathrm{R} 1$ near the city of San Jacinto was about 174 feet below the land surface in September 1959; this well was flowing in 1917. Similarly, the water level in well $4 \mathrm{~S} / 3 \mathrm{~W}-33 \mathrm{R} 1$ near the city of Perris was about 178 feet below the land surface in September 1959; this well is in an area where the water level was about 20 feet below the land surface in March 1904. Both areas now are importing small amounts of water from the Colorado River, at double the cost of water pumped in the area, in an effort to supplement the depleted water reserves.

By the end of the 1959 water year, the ground-water levels in almost all the basins in the western part of Riverside County had dropped to below those of September 1958. Water levels declined in the Riverside, Arlington, Chino, and Temescal basins an average of 3.5 feet; at Palm Springs and Desert Hot Springs, 4.5 feet; and in the Banning Canyon wells, which were flowing in 1958, as much as 60 feet below the land surface.

In Elsinore basin, however, the groundwater level rose an average of 6 feet. The rise is generally attributed to the importation of water from the Colorado River to the valley of the basin. Also, in some areas of Perris Valley, ground-water levels rose about 6 feet probably owing partly to a minor decrease in pumping activity and a trend to more dry-farming operations.

\section{SAN BERNARDINO VALLEY}

The San Bernardino Valley is a relatively deep alluvial valley in the upper Santa Ana River basin, east of metropolitan Los Angeles. Agricultural and urban water needs are supplied from local surface and ground-water sources.

The longest available record of fluctuation in ground-water level is that for the Williams well (1S/3W-17C1). This record (fig. 6), for the period 1892-1959, indicates the response to seasonal changes caused by pumping and recharge and to the long-term changes associated with wet and dry periods. These waterlevel fluctuations indicate a general. cyclic distribution, in time, that coincides closely with that of the wet and dry periods shown on figure 5 .

The rate of decline during the first and second dry periods was about 4.2 feet per year. However, during the current dry period the rate of decline increased to about 10 feet per year, which reflects an increase in the use of ground-water and which can be contrasted with the average rate and duration of recharge during wet periods of record to forecast overdraft in the near future.

The San Bernardino Valley Water Conservation District reported that ground-water levels appear to have resumed a decline that was largely halted temporarily by the very wet 1958 water year. Water levels in most of the wells in the valley were lower in the fall of 1959 than at any time during the entire period of record, the decline generally averaging about 100 feet since October 1944-the beginning of the current dry period. The chief exceptions to this adverse condition are the areas near spreading grounds, which are adjacent to the mountain streams.

In the vicinity of the Williams well, which went dry in July 1956, the water level began to rise in April 1958 as a result of aboveaverage precipitation. However, the recovery 
was short lived; by December 1958 the Williams well was again dry. Water-level records obtained since March 1957, shown in figure 6 , are from a companion well $(1 \mathrm{~S} / 3 \mathrm{~W}-$ 17C3) drilled to replace the Williams well.

\section{SAN GABRIEL VALLEY}

The San Gabriel Valley is a deep alluvial valley in the San Gabriel River basin along the toe of the San Gabriel Mountains. The ground-water storage capacity of these deposits is believed to be about 1.2 million acre-feet in a zone 100 feet thick, ranging from 50 feet above to 50 feet below the January 1933 water level. ${ }^{4}$ The once extensive agricultural acreage in this valley is rapidly becoming urbanized. Most of the water requirements of the valley are met by local ground-water reserves.

The record obtained at the Baldwin Park observation well 1S/10-18 (fig. 6) is assumed to represent ground-water conditions throughout the valley. The average rate of waterlevel decline, which was about 3.9 feet per year during the dry period 1922-36, increased to 8.8 feet per year during the current dry period. During the last few years, this rate of decline has moderated, owing partly to the wet year 1951-52 and partly to the increased use of water imported from the Colorado River.

The Los Angeles County Flood Control District reported that ground-water levels in the San Gabriel Valley continued to be somewhat unstable as ground-water mounds, formed by water-spreading operations in 1958, continued to dissipate. In the central and northern parts of the basin, in the vicinity of Baldwin Park and Santa Fe Dam southwest of Azusa, the water levels declined from 15 to 25 feet during 1959. Around the periphery of the basin, water levels have not shown much fluctuation; although in the tributary basins of Monk Hill, Puente, Glendora, Way Hill, San Dimas, Live Oak, Lower Claremont, and Upper Claremont, ground-water levels recorded at the end of the water year were generally lower than those recorded late in 1958.

\footnotetext{
4 See footnote p. 10.
}

COASTAL PLAIN

The coastal plain is the broad, flat area extending southeastward along the coast from Santa Monica to Newport Beach and inland to the Santa Monica and Santa Ana Mountains, the Puente and San Jose Hills, and lesser foothills. Three major streams, the Santa Ana, San Gabriel, and Los Angeles Rivers, cross the plain and discharge into the ocean. The rich agricultural lands of the plain have been converted gradually into extensive urban and suburban areas. Currently, the coastal plain is the most densely populated and industrialized area of southern California.

The water-bearing deposits underlying the coastal plain are composed of marine and alluvial materials that locally are 2,500 feet or more thick. Prior to 1940 these deposits were still the principal source of water for the area. Because of the rapid increase in water needs during recent years, it has been necessary to import large quantities of water from the Owens Valley and the Colorado River. Even with this imported water, the ground-water reserves have been so depleted that sea water has encroached on these deposits along many parts of the coast.

Fluctuation in ground-water level in the coastal plain has been systematically observed at the Neff well (4S/10-22L2) and its companion wells near Anaheim since 1898. These records (fig. 6) have been used as an index of fluctuation in the water level of the coastal plain. During the 61-year period of record at this site, a net decline of 132 feetfrom 112 feet above sea level to about 20 feet below sea level-was observed. This decline, which has not been uniform, occurred largely during the three dry periods. An average rate of decline of 3.9 feet per year in the first dry period increased to 4.6 feet per year during the second dry period and to 7.6 feet per year in the current dry period. During the last few years, this rate of decline has decreased, owing partly to recharge during the wet year 1951-52 and partly to greater use of imported water.

The Orange County Water District reported a decline in ground-water levels averaging about 6 feet in wells throughout the eastern part of the coastal plain during 1959. At the 
end of the 1959 water year, the average elevation of these ground-water levels was about 16 feet below sea level. About 76,000 acrefeet of water from the Colorado River was spread to replenish the underground basin, and an additional 55,000 acre-feet of water from the Colorado River was purchased by cities and other water users for direct use in areas presently or previously supplied from the District basin.

Near Montebello, in the northern forebay of the plain, the Los Angeles County Flood Control District reported that water levels averaged about 15 feet lower in the fall of 1959 than in the fall of 1958. Water levels in other parts of the central basin were all lower, dropping as much as 10 feet in the Long Beach area north of Signal Hill, 3 feet between Clearwater and Norwalk, 4 feet west of Compton, 10 feet in the Huntington Park area, and from 2 to 4 feet near Vernon. In areas of the west coast basin on the coastal plain where pumping is curtailed, the decline in ground-water levels has averaged less than 1 foot.

\section{OXNARD PLAIN}

The Oxnard plain is a broad coastal plain that is one of the most important agricultural and urban areas in Ventura County. Waterlevel fluctuations recorded by the Ventura County Water Resources Division at well 9-U-9 in the city of Oxnard (fig. 6) reflect changes in the ground-water reserves of the plain. Since 1943 the water level at this site has declined almost continuously. Between 1943 and 1951 the average rate of decline was about 7.4 feet per year. This trend was reversed temporarily by recharge during the wet year 1952, and since 1953 the decline in water level has continued at a rate somewhat less than that before 1952 .

The Ventura County Water Resources Division reported that the water level of the Oxnard plain declined about 4 feet during the year to an elevation of 18 feet below sea level in the fall of 1959. At the same time the water level in Pleasant Valley, an eastward extension of the Oxnard plain, was about 80 feet below sea level. In the Fillmore, Santa Paula, and Mound basins the water levels were about 6 feet lower than they were in the fall of 1958 . The water levels declined an average of $8 \mathrm{feet}$ in the Ventura River and Las Posas basins; but at Thousand Oaks and in the Ojai area the water levels were 40 feet lower than they were in the fall of 1958 .

According to the United Water Conservation District, the water level in Pleasant Valley dropped from 27 to 30 feet within a 30-day period just prior to April 11, 1959. There is evidence of sea-water encroachment in wells near the ocean, and the present area of saltwater contamination extends as much as 1 mile inland.

\section{SANTA MARIA VALLEY}

The fluctuation in water level in well 10/34-14E2 (fig. 6) near the center of the Santa Maria Valley, in the northern part of Santa Barbara County, generally reflects the amount of ground water in storage for a large part of the valley. The records from this well show a continuous and almost uniform decline in water level at a rate of 4.0 feet per year during the dry years 1917-36. As a result of the large ground-water recharge during the wet period extending through 1944 , the water level in this well rose about 35 feet. During the current dry period, the water level declined at an average rate of 7.4 feet per year to the lowest level on record, indicating a substantially increased draft on the groundwater reserves.

Ground-water levels in most wells in the Santa Maria, Santa Ynez, Cuyama, Carpinteria, Goleta, and San Antonio basins have declined owing to below-average precipitation during 1959. However, water levels in some wells showed a rise, which was interpreted as a delayed response to the above-average precipitation of the 1958 water year.

\section{ANTELOPE VALLEY}

Antelope Valley, in Los Angeles and Kern Counties, is in the extreme west end of the Mojave Desert. Parts of this aridvalley have been farmed successfully for more than 60 years. However, the steadily increasing water needs for agricultural and other uses have created a critical overdraft in the valley.

Figure 6 shows graphically the fluctuation in water level in a well near Lancaster, which 
is used as an index of fluctuation in water level in the large heavily pumped part of the valley. During the last 28-year period, the water level in this well and in nearby wells has declined about 150 feet. This decline, which persisted even during the wet years, clearly indicates that withdrawal exceeded recharge. The rate of decline, which was about 3.4 feet per year during the 1922-36 dry period, has increased to 8.1 feet per year during the current dry period.

The Los Angeles County Flood Control District reported that the ground-water levels in the Lancaster basin have declined an average of 4 feet during the 1959 water year, whereas they had declined from 2 to 3 feet during 1958.

\section{ARTIFICIAL RECHARGE OF GROUND WATER}

During the 1959 water year, the Metropolitan Water District of Southern California sold about 195,000 acre-feet of water from the Colorado River, at a cost of more than $\$ 2.3$ million, to Los. Angeles and Orange Counties chiefly to retard the rapid rate of decline in ground-water levels. This water was permitted either to infiltrate into the stream-channel deposits or to spread into highly permeable, specially prepared basins overlying the main ground-water bodies.

An additional 13,000 acre-feet of local storm runoff from the mountains and foothills during the 1959 water year was diverted from

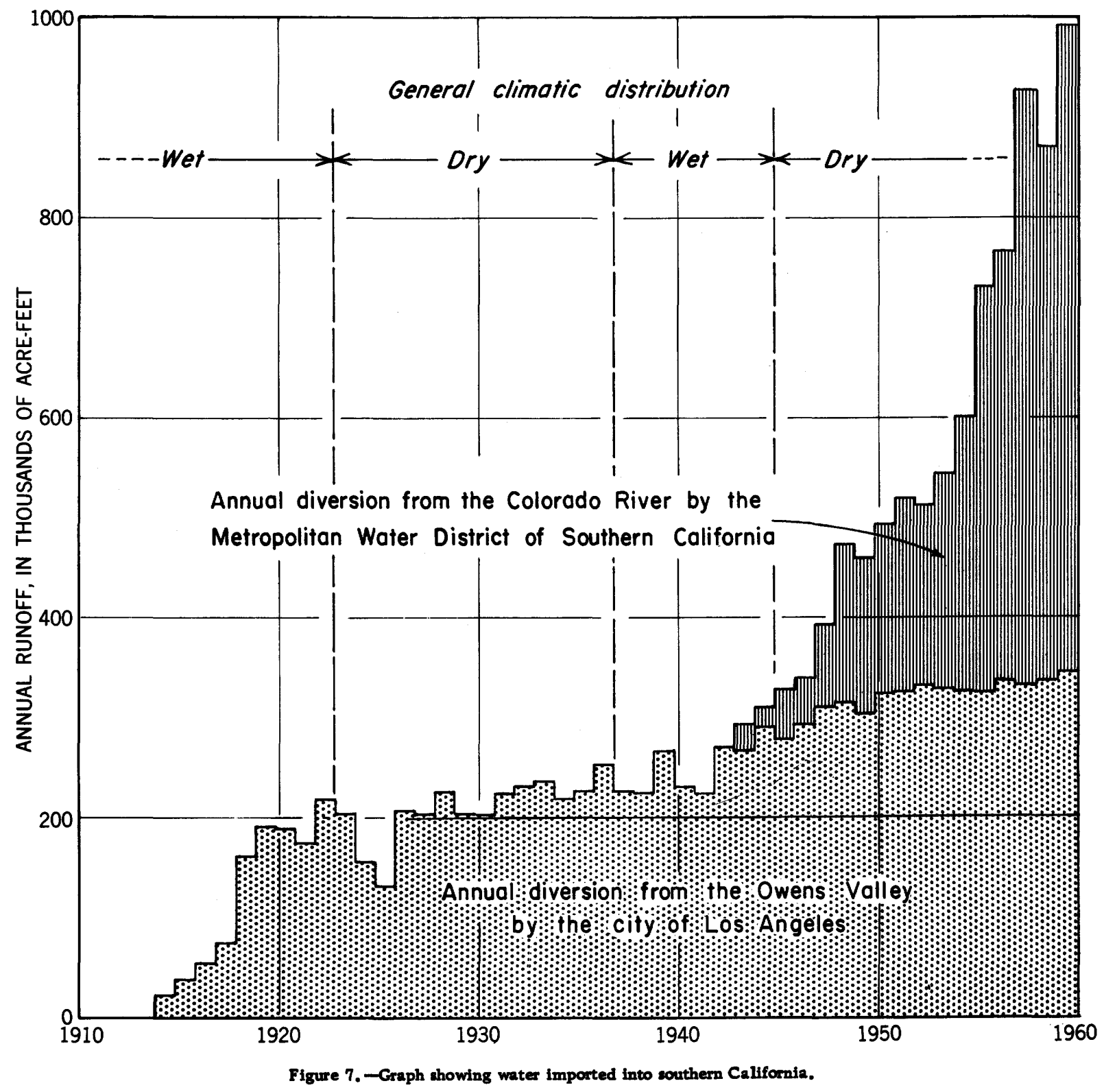


natural stream channels into the specially prepared basins to recharge the groundwater reservoirs in Los Angeles County. Farther north, in Ventura County, about 20,000 acre-feet of local storm runoff was released from Piru Lake to the Saticoy and El Rio spreading grounds to recharge the groundwater reservoirs in the Santa Clara Valley.

About 3,600 acre-feet of water from the Colorado River was put into injection wells along the coast in the vicinity of Manhattan Beach to maintain a fresh-water barrier against sea-water encroachment.

\section{IMPORTED WATER}

Southern California is a predominantly arid region which has less than 2 percent of the State's natural water supplies. Consequently, to satisfy the ever-increasing water requirements of the area, water must be imported from distant sources.

Since 1913 the city of Los Angeles has imported water from the Owens Valley, which lies east of the Sierra Nevada and some 250 miles to the north. During the 1959 water year the Los Angeles aqueduct, operating at full capacity as in previous years, delivered 345,000 acre-feet from the Owens Valley to the Los Angeles area.

By means of a 1,617-foot pumping lift and a 242-mile aqueduct, the Metropolitan Water District of Southern California delivered 647,000 acre-feet of water from the Colorado River to the greater Los Angeles and San Diego areas during the 1959 water year.

As indicated on figure 7 these annual imports have increased from 329,000 acre-feet in 1945 to 992,000 acre-feet in 1959 - a net increase of over 200 percent. More than 45 percent of the annual water requirements in the coastal areas are now met by imported water.

\section{RUNOFF FOR THE WATER YEAR 1957-58}

Table 4 presents runoff data for the water year ending September 30, 1958, from all gaging stations in southern California for which records are published currently by the U.S. Geological Survey. The mean and median values of the annual runoff for the period of record and the relation of the annual runoff to the base mean are also given for the stations which have a sufficiently long period of record.

\section{AREAL DISTRIBUTION}

The normal path of storms moving over southern California is such that the precipitation along the coast generally decreases southward. The eastward movement of the storms is blocked by the high mountains whose barrier effect causes the greatest precipitation in the region to occur on the windward sides. Across the mountains, the precipitation decreases rapidly to almost nothing in the desert areas.

A generalized areal distribution of the annual runoff for the water year ending on September 30,1958 , is shown on figure 8 . The runoff quantities used to define this distribution were obtained from table 4; the quantities are relative as they express the departure as percentages of the runoff for the 1958 water year from the mean of the 35 year period 1920-55.

The departure of the 1957-58 runoff from the 35-year base means reflects the relatively wet year prevalent in all except the southernmost parts of southern California. The average departure for the 1958 water year was +104 percent. For the 1952 water year, the only other relatively wet year in the current dry period, the average departure from the 35-year base mean at these same stations was about +77 percent.

\section{UNIT RUNOFF}

Unit rates of runoff generally decreases rapidly as the streams flow cross the valleyfloor areas and discharge into the ocean. In the predominantly agricultural areas, the 1958 runoff into the ocean from the basins of the Tia Juana and San Luis Rey Rivers was almost negligible. In sharp contrast, and reflecting precipitation on roofs of buildings and paved streets in the Beverly Hills and Hollywood areas, runoff to the ocean from the Ballona Creek basin was 486 acre-feet per square mile or about 9.1 inches of water over the entire basin. 


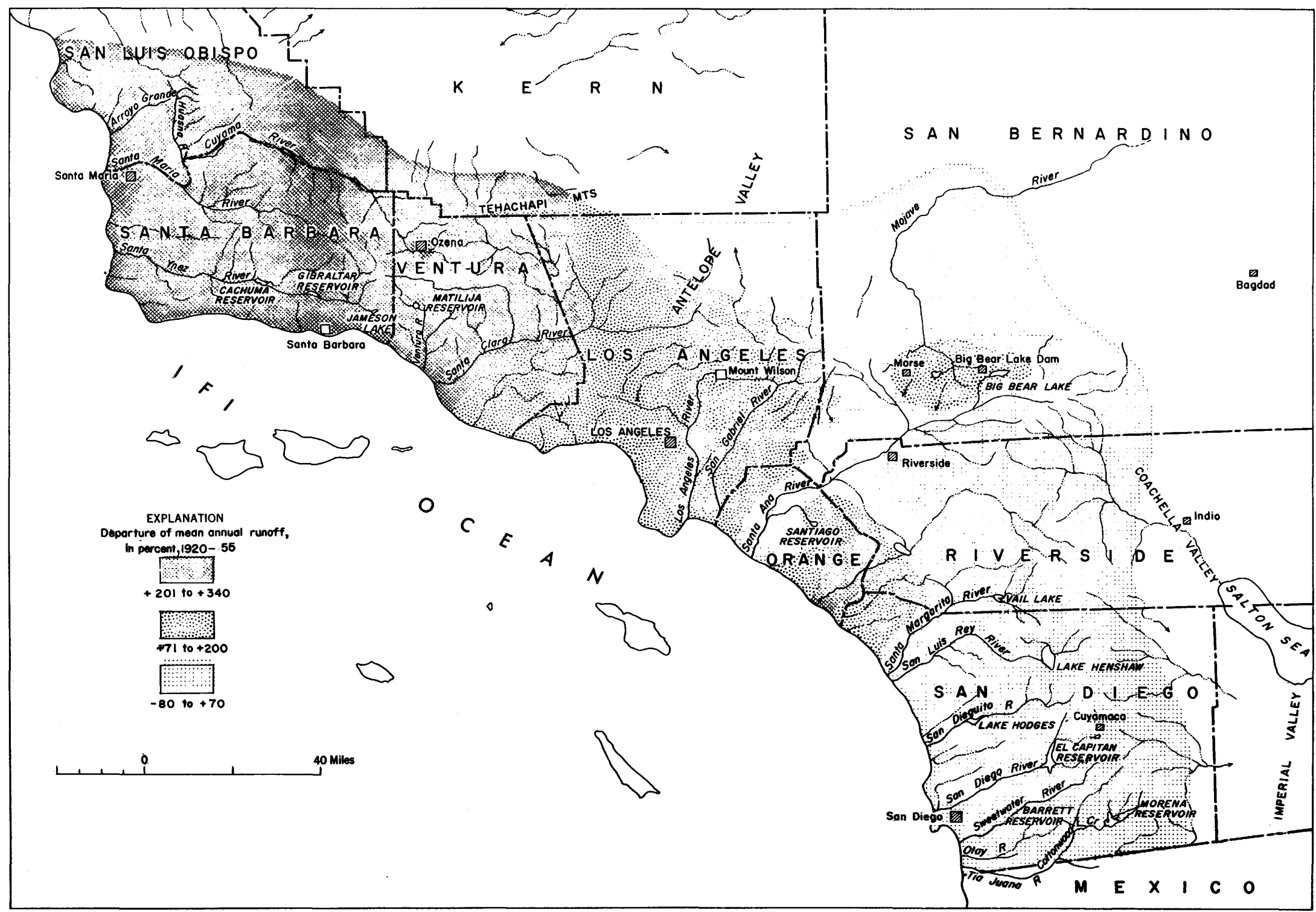

Figure 8. - Map showing areal distribution of runoff for the water year: 1957-58. 
Table 4.-Runoff for the water year 1957-58

\begin{tabular}{|c|c|c|c|c|c|c|c|c|}
\hline \multirow[b]{2}{*}{ Stream } & \multirow[b]{2}{*}{$\begin{array}{l}\text { Drain- } \\
\text { age } \\
\text { area } \\
\text { (sq mi) }\end{array}$} & \multicolumn{3}{|c|}{$1957-58$ runoff } & \multicolumn{3}{|c|}{ Period of record } & Base mean \\
\hline & & $\begin{array}{c}\text { Acre- } \\
\text { feet }\end{array}$ & $\begin{array}{c}\text { Acre- } \\
\text { feet } \\
\text { per } \\
\text { square } \\
\text { mile }\end{array}$ & $\begin{array}{l}\text { Depar- } \\
\text { ture } \\
\text { from } \\
\text { base } \\
\text { mean } \\
\text { (per- } \\
\text { cent) }\end{array}$ & $\begin{array}{l}\text { Length } \\
\text { (years) }\end{array}$ & $\begin{array}{l}\text { Mean } \\
\text { annual } \\
\text { runoff } \\
\text { (acre- } \\
\text { ft) }\end{array}$ & $\begin{array}{c}\text { Median } \\
\text { annual } \\
\text { runoff } \\
\text { (acre- } \\
\text { ft) }\end{array}$ & $\begin{array}{c}\text { Mean } \\
\text { annual } \\
\text { runoff } \\
1920-55 \\
\text { (acre-ft) }\end{array}$ \\
\hline
\end{tabular}

PACIFIC SLOPE BASINS

Tia Juana River basin

\begin{tabular}{|c|c|c|c|c|c|c|c|c|}
\hline $\begin{array}{l}\text { Cottonwood Creek at Morena } \\
\text { Dam }^{1}\end{array}$ & 120 & 2,680 & 22.3 & -76 & 22 & 10,060 & 5,300 & 11,250 \\
\hline Cottonwood Creek at Barrett & & & & & & & & \\
\hline $\begin{array}{l}\text { Dam, near Dulzura } \\
\text { Cottonwood Creek above }\end{array}$ & 250 & 10,590 & 42.4 &.----- & 13 & ---1 & & \\
\hline Tecate Creek near Dulzura & 316 & 2,760 & 8.73 & & 22 & 7,190 & 1,500 & ------ \\
\hline Campo Creek near Campo & 84.0 & 64 & .76 & & 22 & 2,100 & 1,200 & $--\ldots-n-1-$ \\
\hline Tia Juana River near Dulzura & 478 & 3,240 & 6.78 & & 22 & 11,510 & 3,500 & -......... \\
\hline Tia Juana River near Nestor _ & 668 & 2,290 & 1.37 & & 23 & 35,040 & 8,000 & $-\ldots-n$ \\
\hline
\end{tabular}

Otay River basin

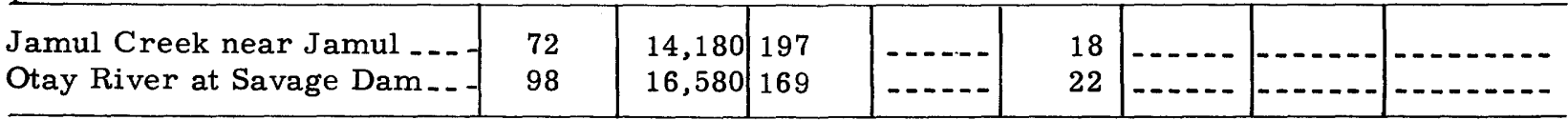

Sweetwater River basin

Sweetwater River near

Descanso

Sweetwater River at Loveland

Dam, near Alpine ${ }^{2}$

Sweetwater River at

Sweetwater Dam².

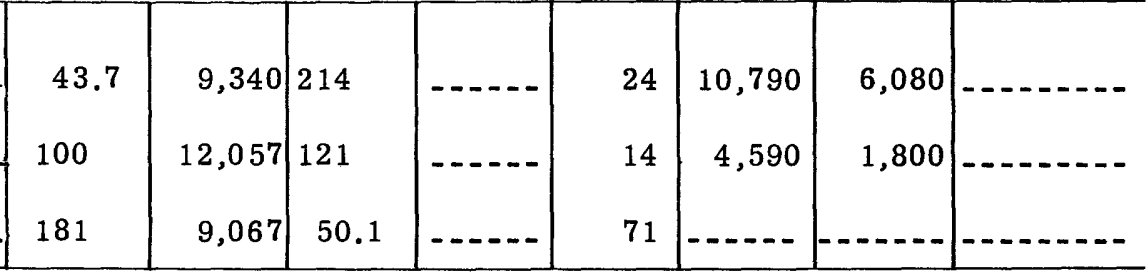

San Diego River basin

Boulder Creek at Cuyamaca

Reservoir, near Julian ${ }^{3}$

San Diego River at El

Capitan Dam ${ }^{1}$

San Diego River near Santee.-

\begin{tabular}{|l|r|r|r|r|r|r|r}
\hline 12.0 & 6,490 & 541 & +49 & 18 & 3,870 & 2,000 & 4,360 \\
190 & 42,080 & 221 & $-\ldots-0$ & 13 & & & \\
380 & 8,150 & 21.4 & -60 & 43 & 20,130 & 3,600 & 20,410 \\
\hline
\end{tabular}

San Dieguito River basin

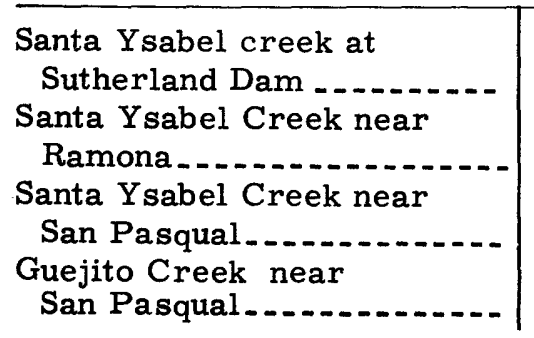

\begin{tabular}{c|r|r|r|}
57 & 14,540 & 255 & +18 \\
110 & 12,000 & 109 & $\ldots-\ldots$ \\
128 & 14,390 & 112 & $-\ldots .-$ \\
24 & 4,270 & 178 & $\ldots \ldots$
\end{tabular}
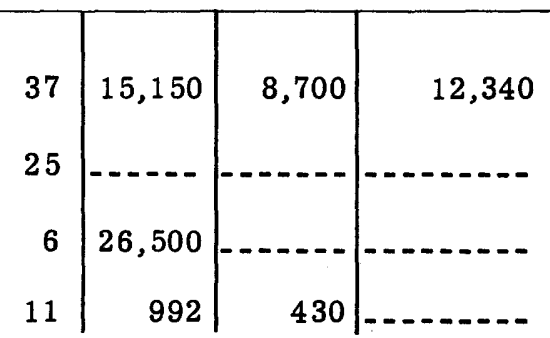

See fontnotes at end of table. 
Table 4.-Runoff for the water year 1957-58-Continued

\begin{tabular}{|c|c|c|c|c|c|c|c|c|}
\hline \multirow[b]{2}{*}{ Stream } & \multirow[b]{2}{*}{$\begin{array}{c}\text { Drain- } \\
\text { age } \\
\text { area } \\
\text { (sq } \mathrm{mi} \text { ) }\end{array}$} & \multicolumn{3}{|c|}{$1957-58$ runoff } & \multicolumn{3}{|c|}{ Period of record } & Base mean \\
\hline & & $\begin{array}{c}\text { Acre- } \\
\text { feet }\end{array}$ & $\begin{array}{l}\text { Acre- } \\
\text { feet } \\
\text { per } \\
\text { square } \\
\text { mile }\end{array}$ & $\begin{array}{c}\text { Depar- } \\
\text { ture } \\
\text { from } \\
\text { base } \\
\text { mean } \\
\text { (per- } \\
\text { cent) }\end{array}$ & $\begin{array}{l}\text { Length } \\
\text { (years) }\end{array}$ & $\begin{array}{l}\text { Mean } \\
\text { annual } \\
\text { runoff } \\
\text { (acre- } \\
\text { ft) }\end{array}$ & $\begin{array}{l}\text { Median } \\
\text { annual } \\
\text { runoff } \\
\text { (acre- } \\
\mathrm{ft} \text { ) }\end{array}$ & $\begin{array}{c}\text { Mean } \\
\text { annual } \\
\text { runoff } \\
1920-55 \\
\text { (acre-ft) }\end{array}$ \\
\hline
\end{tabular}

San Dieguito River basin-Continued

Santa Maria Creek near
Ramona...
San Dieguito River near
San Pasqual _...
San Dieguito River at Lake
Hodges ${ }^{1}$.

\begin{tabular}{c|r|r|r}
58 & 5,540 & 95.5 & $\ldots \ldots$ \\
250 & 14,500 & 58.0 & $\ldots \ldots$ \\
303 & 12,610 & 41.6 & $\ldots \ldots$ \\
\hline
\end{tabular}
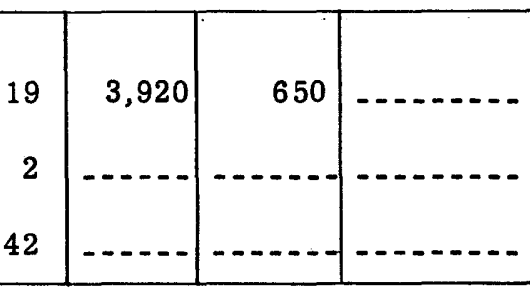

San Luis Rey River basin

West Fork San Luis Rey River near Warner Springs

San Luis Rey River at Lake Henshaw, near Mesa Grande 4

San Luis Rey River at Monserate Narrows, near Pala _......................

San Luis Rey River near

Bonsall

San Luis Rey River at

Oceanside.

\begin{tabular}{l|r|r|r|r|r|r|r}
25.6 & 15,620 & 610 & $\ldots \ldots$ & 4 & $\ldots \ldots$ & & \\
209 & 24,140 & 116 & -1 & 36 & 21,500 & 13,000 & 24,410 \\
383 & 12,830 & 33.5 & $\ldots \ldots$ & 15 & 8,180 & 2,800 & $\ldots \ldots$ \\
514 & 5,120 & 9.96 & -78 & 29 & 17,450 & 6,400 & 21,970 \\
557 & 2,720 & 4.88 & $\ldots \ldots$ & 26 & 14,840 & 1,400 & $\ldots \ldots$ \\
\hline
\end{tabular}

Santa Margarita River basin

Temecula Creek near

Aguanga

Temecula Creek at Vail Darn, near Temecula ............

Murrieta Creek at Temecula.

Santa Margarita River near

Temecula ..................

Santa Margarita River near

Fallbrook

De Luz Creek near Fallbrook

Santa Margarita River at

Ysidora.

\begin{tabular}{|c|c|c|c|c|c|c|c|}
\hline - & 9,070 & - . & 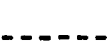 & 1 & - - - - & - & - \\
\hline 319 & 11,060 & 34.7 & +13 & 35 & 8,740 & 4,900 & 9,810 \\
\hline 220 & 14,220 & 64.6 & +52 & 28 & 7,750 & 2,000 & 9,380 \\
\hline 592 & 17,960 & 30.3 & -6 & 35 & 17,100 & 7,200 & 19,030 \\
\hline - & 19,200 & - & -17 & 33 & 21,460 & 8,500 & 23,090 \\
\hline 47.9 & 20,810 & 434 & - - & 7 & 5,760 & $-\ldots$ & - \\
\hline 740 & 30,370 & 41.0 & +11 & 34 & 24,800 & 9,400 & 27,450 \\
\hline
\end{tabular}

San Juan Creek basin

San Juan Creek near San

San Juan Capistrano........

Arroyo Trabuco near

San Juan Capistrano ${ }^{5}$

\begin{tabular}{c|c}
110 & 28,440 \\
36.5 & 12,060
\end{tabular}

\begin{tabular}{|c|c|}
\hline 259 & $\ldots$. \\
330 & +242 \\
\hline
\end{tabular}
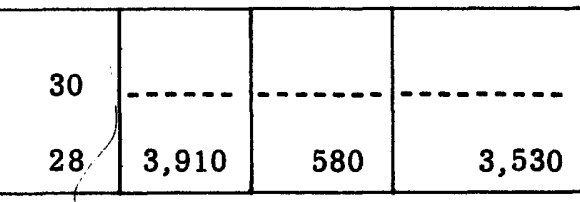

See footnotes at end of takle. 
Table 4.-Runoff for the water year 1957-58-Continued

\begin{tabular}{|c|c|c|c|c|c|c|c|c|}
\hline \multirow[b]{2}{*}{ Stream } & \multirow[b]{2}{*}{$\begin{array}{c}\text { Drain- } \\
\text { age } \\
\text { area } \\
\text { (sq } \mathrm{mi} \text { ) }\end{array}$} & \multicolumn{3}{|c|}{$1957-58$ runoff } & \multicolumn{3}{|c|}{ Period of record } & \multirow{2}{*}{\begin{tabular}{|c} 
Base mean \\
Mean \\
annual \\
runoff \\
$1920-55$ \\
(acre-ft)
\end{tabular}} \\
\hline & & $\begin{array}{c}\text { Acre- } \\
\text { feet }\end{array}$ & $\begin{array}{l}\text { Acre } \\
\text { feet } \\
\text { per } \\
\text { square } \\
\text { mile }\end{array}$ & $\begin{array}{l}\text { Depar- } \\
\text { ture } \\
\text { from } \\
\text { base } \\
\text { mean } \\
\text { (per- } \\
\text { cent) }\end{array}$ & $\begin{array}{l}\text { Length } \\
\text { (years) }\end{array}$ & $\begin{array}{l}\text { Mean } \\
\text { annual } \\
\text { runoff } \\
\text { (acre - } \\
\text { ft) }\end{array}$ & $\begin{array}{c}\text { Median } \\
\text { annual } \\
\text { runoff } \\
\text { (acre- } \\
\mathrm{ft} \text { ) }\end{array}$ & \\
\hline \multicolumn{9}{|c|}{ Aliso Creek basin } \\
\hline Aliso Creek at El Toro ${ }^{5}$ & 8.5 & 1,380 & 162 & +168 & 28 & 577 & 220 & 514 \\
\hline
\end{tabular}

Peters Canyon Wash basin

\begin{tabular}{l|l|l|l|l|l|l|l|l}
\hline San Diego Creek near Irvine _ & $\ldots . .$. & 4,330 & $\ldots . .$. & $\ldots . .$. & 9 & 1,460 & $\ldots . . .$. & $\ldots . . . .$. \\
\hline
\end{tabular}

Santa Ana River basin

\begin{tabular}{|c|c|c|c|c|c|c|c|c|}
\hline Santa Ana River near & & & & & & & & \\
\hline Mentone & 202 & 67,230 & 333 & +21 & 62 & 61,260 & 51,700 & 55,680 \\
\hline Mill Creeknear Yucaipa & 42.9 & 42,260 & 985 & +72 & 30 & 24,110 & 17,400 & 24,500 \\
\hline Mill Creek near Mentone .... & 51.7 & 13,380 & 259 & 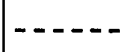 & 19 & 2,500 & 510 & ----- \\
\hline $\begin{array}{l}\text { Plunge Creek near East } \\
\text { Highlands }\end{array}$ & 16.6 & 12,200 & 735 & & 39 & & & \\
\hline $\begin{array}{l}\text { Santa Ana River near San } \\
\text { Bernardino }\end{array}$ & 302 & 15,430 & 51.1 & & 13 & 6.750 & 1300 & \\
\hline $\begin{array}{l}\text { Little San Gorgonio Creek } \\
\text { near Beaumont }\end{array}$ & 2.61 & 129 & 49.4 & & 10 & 65 & 72 & \\
\hline $\begin{array}{l}\text { San Timoteo Creek near } \\
\text { Redlands }\end{array}$ & 123 & 1,200 & 9.76 & -8 & 32 & 1,060 & 360 & 1,300 \\
\hline $\begin{array}{l}\text { San Timoteo Creek near } \\
\text { Loma Linda }\end{array}$ & & 2,080 & & & 4 & & & \\
\hline $\begin{array}{r}\text { East } \mathrm{T} \\
\text { Arro } \\
\text { Water }\end{array}$ & 8.6 & 6,200 & 721 & +81 & 38 & 3,420 & 2,500 & 3,420 \\
\hline $\begin{array}{l}\text { n Creek near } \\
\text { ngs }\end{array}$ & 4.55 & 3,430 & 754 & +81 & 40 & 1,980 & 1,400 & $1 ; 900$ \\
\hline ighland .... & 19.8 & 20,660 & 1,040 & +174 & 39 & 7,720 & 5,600 & 7,530 \\
\hline Devil & & & & & & & & \\
\hline Bern & 6.16 & 5,350 & 869 & +129 & 39 & 2,390 & 1,700 & 2,340 \\
\hline Lytle Cre & 46.9 & 35,400 & 755 & +19 & 54 & 31,270 & 25,900 & 29,730 \\
\hline $\begin{array}{l}\text { Cajon Creeknear Keenbrook } \\
\text { Lone Pine Creek near }\end{array}$ & 40.9 & 9,360 & 229 & +39 & 38 & 6,520 & 4,300 & 6,720 \\
\hline 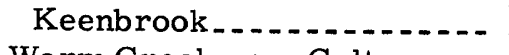 & 15.0 & 880 & 58.7 & -24 & 27 & 927 & 430 & 1,160 \\
\hline $\begin{array}{l}\text { Warm Creek near Colton---- } \\
\text { Santa Ana River at Riverside }\end{array}$ & 259 & 15,820 & 61.1 & 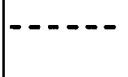 & 38 & $\ldots \ldots$ & -1 & \\
\hline Arlington .. & 858 & 34,030 & 39.7 & -37 & 28 & 39,850 & 29,900 & 53,860 \\
\hline $\begin{array}{l}\text { Day Creek near Etiwanda } \\
\text { Cucamonga Creek near }\end{array}$ & 4.58 & 6,230 & 1,360 & +58 & 29 & 3,910 & 3,000 & 3,950 \\
\hline $\begin{array}{l}\text { Upland } \\
\text { San Jacinto River near San }\end{array}$ & 10.1 & 12,370 & 1,220 & +117 & 29 & 5,650 & 4,100 & 5,710 \\
\hline Jacinto & 140 & 40,190 & 287 & +64 & 38 & 23,940 & 13,600 & 24,550 \\
\hline $\begin{array}{l}\text { Baut } \\
\text { San J }\end{array}$ & 39.4 & 2,600 & 66.0 & $\ldots$ & 11 & 565 & 7 & \\
\hline Elsinore. & 1717 & 9,900 & 13.8 & & 31 & 7,820 & 72 & \\
\hline
\end{tabular}

See footnotes at end of table. 
Table 4.-Runoff for the water year 1957-58-Continued

\begin{tabular}{|c|c|c|c|c|c|c|c|c|}
\hline \multirow[b]{2}{*}{ Stream } & \multirow[b]{2}{*}{$\begin{array}{l}\text { Drain- } \\
\text { age } \\
\text { area } \\
\text { (sq } \mathrm{mi})\end{array}$} & \multicolumn{3}{|c|}{ 1957-58 runoff } & \multicolumn{3}{|c|}{ Period of record } & \multirow{2}{*}{\begin{tabular}{|c|} 
Base mean \\
Mean \\
annual \\
runoff \\
$1920-55$ \\
(acre-ft)
\end{tabular}} \\
\hline & & $\begin{array}{c}\text { Acre- } \\
\text { feet }\end{array}$ & $\begin{array}{l}\text { Acre } \\
\text { feet } \\
\text { per } \\
\text { square } \\
\text { mile }\end{array}$ & $\begin{array}{c}\text { Depar- } \\
\text { ture } \\
\text { from } \\
\text { base } \\
\text { mean } \\
\text { (per- } \\
\text { cent) }\end{array}$ & $\begin{array}{l}\text { Length } \\
\text { (years) }\end{array}$ & $\begin{array}{c}\text { Mean } \\
\text { annual } \\
\text { runoff } \\
\text { (acre- } \\
\text { ft) }\end{array}$ & $\begin{array}{c}\text { Mediun } \\
\text { annual } \\
\text { runoff } \\
\text { (acre- } \\
\text { ft) }\end{array}$ & \\
\hline
\end{tabular}

Santa Ana River basin-Continued

\begin{tabular}{|c|c|c|c|c|c|c|c|c|}
\hline $\begin{array}{l}\text { Temescal Creek near Corona } \\
\text { San Antonio Creek near }\end{array}$ &.--- & 218 & & & 29 & 2,620 & 36 & \\
\hline $\begin{array}{l}\text { Claremont } \\
\text { Santa Ana River below Prado }\end{array}$ & 16.9 & 34,460 & 2,040 & +114 & 41 & 16,000 & 11,600 & 16,120 \\
\hline $\begin{array}{l}\text { Dam } \\
\text { Santa Ana River at county } \\
\text { line below Prado Dam }\end{array}$ & 1,462 & 75,700 & 51.8 & $-\ldots$ & 18 & $\cdots$ & & \\
\hline $\begin{array}{r}\text { Iine, } \\
\text { Dantia }\end{array}$ & 63.2 & 24.850 & 393 & +121 & 27 & 13,030 & 8.000 & 11,220 \\
\hline antiago Creel & & & & & & & & \\
\hline$V_{j}$ & 83.8 & 2,060 & 24.6 & $-\ldots-$ & 38 & $-\cdots$ & & \\
\hline$C$ mole Con & 96.6 & 2,310 & 23.9 & -51 & 25 & 3,780 & 580 & 4,750 \\
\hline Santa Ana River at Santa Ana & 1,625 & 19,340 & 11.9 & 0 & 35 & 14,480 & 2,100 & 19,300 \\
\hline
\end{tabular}

San Gabriel River basin

East Fork San Gabriel River near Camp Bonita ${ }^{6}$.

West Fork San Gabriel River at Camp Rincon 6 .

San Gabriel River near Azusa

Rogers Creek near Azusa

Fish Creek near Duarte

San Gabriel River below Santa Fe Dam, near Baldwin Park.

San Dimas Creek below San Dimas Dam ${ }^{6}$

Dalton Creek near Glendora ..

Little Dalton Creek near Glendora ${ }^{6}$

San Jóse Creek near Whittier ${ }^{6}$. San Gabriel River at $\mathrm{Pico}{ }^{6}$

San Gabriel River at Spring Street, near Los Alamitos.Brea Creek below Brea Dam, near Fullerton

Brea Creek at Fullerton ${ }^{5}$

Fullerton Creek below

Fullerton Dam, near Brea

Fullerton Creek at Fullerton ${ }^{5}$ -

Coyote Creek near Artesia ${ }^{6}$.

Carbon Creek near Yorba

Linda

\begin{tabular}{|c|c|c|c|c|c|c|c|}
\hline 88.2 & 112,700 & 1,280 & +130 & 25 & 52,850 & 34,000 & 48,910 \\
\hline 102 & 106,100 & 1,040 & +114 & 31 & 47,780 & 24,600 & 49,640 \\
\hline 211 & 239.000 & 1.130 & +129 & 63 & 111,500 & 78,900 & 104,200 \\
\hline 6.4 & 5,280 & 825 & +135 & 41 & 2,160 & 1,200 & 2,240 \\
\hline 6.5 & 5,680 & 874 & +89 & 41 & 2,880 & 1,700 & 3,010 \\
\hline 231 & 91,530 & 395 & $-\cdots$ & 16 & $---\cdots$ & $\cdots$ & - \\
\hline 16.2 & 6,520 & 402 & $\ldots$ & 2 & $---n-$ & -- & 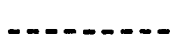 \\
\hline 7.5 & 3,110 & 415 & $\ldots$ & 38 & $-\ldots-$ & $\ldots$ & $-\ldots$ \\
\hline 2.7 & 1,400 & 519 & $\ldots$ & 20 & 514 & 220 & 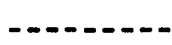 \\
\hline 85.2 & 17,300 & 203 & +195 & 29 & 6,280 & 3,900 & 5,860 \\
\hline 206 & ${ }^{7} 82,190$ & 399 & +140 & 30 & 32,830 & 14,000 & 34,270 \\
\hline 216 & 22,920 & 106 & $-\ldots$ & 31 & 18,560 & 2,000 & $-\cdots$ \\
\hline 23.4 & 1,520 & 65.0 & $-\cdots$ & 16 & 514 & 140 & 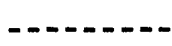 \\
\hline 26.2 & 1,750 & 66.8 & $\ldots . .$. & 28 & 852 & 360 & 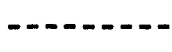 \\
\hline 3.05 & 1,210 & 397 & --- & 17 & 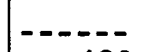 & $-\cdots$ & 4 \\
\hline 6.2 & 1,120 & 182 & $-\ldots$ & 23 & 420 & 170 & - \\
\hline 110 & 15,680 & 143 & +179 & 29 & 6,020 & 3,200 & 5,620 \\
\hline 20.4 & 1,430 & 70.1 & $-\cdots$ & 9 & 304 & $e^{-1}$ & 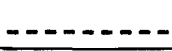 \\
\hline
\end{tabular}

See footnotes at end of table. 
Table 4.-Runoff for the water year 1957-58-Continued

\begin{tabular}{|c|c|c|c|c|c|c|c|c|}
\hline \multirow[b]{2}{*}{ Stream } & \multirow[b]{2}{*}{$\begin{array}{l}\text { Drain - } \\
\text { age } \\
\text { area } \\
\text { (sq } \mathrm{mi})\end{array}$} & \multicolumn{3}{|c|}{$1957-58$ runoff } & \multicolumn{3}{|c|}{ Period of record } & \multirow{2}{*}{\begin{tabular}{|c} 
Base mean \\
\\
Mean \\
annual \\
runoff \\
$1920-55$ \\
(acre-ft)
\end{tabular}} \\
\hline & & $\begin{array}{l}\text { Acre- } \\
\text { feet }\end{array}$ & $\begin{array}{l}\text { Acre } \\
\text { feet } \\
\text { per } \\
\text { square } \\
\text { mile }\end{array}$ & $\begin{array}{l}\text { Depar- } \\
\text { ture } \\
\text { from } \\
\text { base } \\
\text { mean } \\
\text { (per- } \\
\text { cent) }\end{array}$ & $\mid \begin{array}{l}\text { Length } \\
\text { (years) }\end{array}$ & $\begin{array}{c}\text { Mean } \\
\text { annual } \\
\text { runoff } \\
\text { (acre- } \\
\text { ft) }\end{array}$ & $\begin{array}{l}\text { Median } \\
\text { annual } \\
\text { runoff } \\
\text { (acre- } \\
\text { ft) }\end{array}$ & \\
\hline
\end{tabular}

Los Angeles River basin

\begin{tabular}{|c|c|c|c|c|c|c|c|c|}
\hline $\begin{array}{l}\text { Los Angeles River at } \\
\text { Sepulveda Dam }\end{array}$ & 155 & ${ }^{8} 41,110$ & 265 & & & & & \\
\hline Pacoima Creek near San & & 41,110 & 200 & $--\ldots$ & 15 & 14,460 & 10,000 & \\
\hline $\begin{array}{l}\text { Fernando } \\
\text { Tujunga Creek below Mill }\end{array}$ & 28.2 & 15,890 & 563 & +130 & 41 & 6,730 & 3,200 & 6,920 \\
\hline Creek, near Colby Ranch & 64.9 & 19,970 & 308 & - . - . & 10 & 5,340 & 1,900 & -. \\
\hline $\begin{array}{l}\text { Tujunga Creek near } \\
\text { Sunland } 6\end{array}$ & & & & & & & & \\
\hline $\begin{array}{l}\text { Sunland } 6 \\
\text { Haines Creeknear Tujunga }\end{array}$ & 106 & 38,880 & 367 & +83 & 41 & 20,270 & 10,900 & 21,190 \\
\hline $\begin{array}{l}\text { Haines Creek near Tujunga } \\
\text { Little Tujunga Creek near }\end{array}$ & 1.2 & 195 & 162 & 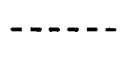 & 26 & 275 & 140 & - n...... \\
\hline $\begin{array}{l}\text { San Fernando }{ }^{6} \\
\text { Tujunga Creek below Hansen }\end{array}$ & 21.0 & 3,440 & 164 & +70 & 30 & 1,850 & 510 & 2,020 \\
\hline Los Angeles River at Los & 148 & 33,560 & 227 &...-- & 18 & 15,220 & 2,900 & -- \\
\hline Angeles ${ }^{6} \ldots$ & 510 & 91,020 & 178 & +123 & 29 & 42,930 & 25,300 & 40,790 \\
\hline $\begin{array}{l}\text { Arroyo Seco near Pasadena - - } \\
\text { Los Angeles River near }\end{array}$ & 16.4 & 11,290 & 688 & +80 & 44 & 6,640 & 3,600 & 6,270 \\
\hline $\begin{array}{l}\text { Downey }{ }^{6} \\
\text { Sawpit Creek near }\end{array}$ & 614 & 134,900 & 210 & $-\ldots$ & 30 & 70,950 & 47,100 & \\
\hline $\begin{array}{l}\text { Monrovia } \\
\text { Santa Anita Creek near }\end{array}$ & 5.3 & 1,490 & 281 & -21 & 41 & 1,810 & 1,400 & 1,880 \\
\hline $\begin{array}{l}\text { Sierra Madre } \\
\text { Little Santa Anita Creek }\end{array}$ & 10.5 & 11,480 & 109 & +163 & 42 & 4,260 & 2,750 & 4,360 \\
\hline $\begin{array}{l}\text { near Sierra Madre } \\
\text { Eaton Creek near }\end{array}$ & 1.9 & 1,470 & 774 & +121 & 41 & 644 & 360 & 665 \\
\hline $\begin{array}{l}\text { Pasadena } \\
\text { Rio Hondo above Whittier }\end{array}$ & 6.5 & 3,490 & 537 & +24 & 40 & 2,660 & 1,700 & 2,820 \\
\hline $\begin{array}{l}\text { Narrows Dam } \\
\text { Rio Hondo near Montebello }\end{array}$ & 115 & $\begin{array}{r}45,810 \\
9119,300\end{array}$ & 1,040 & $-\cdots$ & $\begin{array}{r}2 \\
30\end{array}$ & 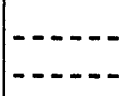 & - n & -- \\
\hline $\begin{array}{l}\text { Mission Creek near } \\
\text { Montebello } 6 \\
\text { Mission Creek below }\end{array}$ & 6 & 2,660 & 443 & & 28 & 10,860 & 11,600 & \\
\hline Whittier Narrows Dam $\ldots$ & $-\ldots$ & 2,590 & $\cdots$ & $-\cdots$ & 2 & & & \\
\hline $\begin{array}{l}\text { Rio Hondo near Downey }{ }^{6} \\
\text { Los Angeles River at Long }\end{array}$ & 140 & 30,270 & 216 & & 30 & 19,400 & 8,000 & \\
\hline Beach $^{6} \ldots \ldots$ & $\ldots$ & 191,600 & & +118 & 29 & 104,300 & 68,800 & 88,040 \\
\hline
\end{tabular}

Ballona Creek basin

\begin{tabular}{l}
$\begin{array}{l}\text { Ballona Creek near Culver } \\
\text { City }^{6} \text {. }\end{array}$ \\
\hline
\end{tabular}

See footnotes at end of table. 
Table 4.-Runoff for the water year 1957-58-Continued

\begin{tabular}{|c|c|c|c|c|c|c|c|c|}
\hline \multirow[b]{2}{*}{ Stream } & \multirow[b]{2}{*}{$\begin{array}{l}\text { Drain- } \\
\text { age } \\
\text { area } \\
\text { (sq } \mathrm{mi} \text { ) }\end{array}$} & \multicolumn{3}{|c|}{$1957-58$ runoff } & \multicolumn{3}{|c|}{ Period of record } & \multirow{2}{*}{\begin{tabular}{|c} 
Base mean \\
\\
Mean \\
annual \\
runoff \\
$1920-55$ \\
(acre-ft)
\end{tabular}} \\
\hline & & $\begin{array}{l}\text { Acre- } \\
\text { feet }\end{array}$ & $\begin{array}{l}\text { Acre } \\
\text { feet } \\
\text { per } \\
\text { square } \\
\text { mile }\end{array}$ & $\begin{array}{c}\text { Depar- } \\
\text { ture } \\
\text { from } \\
\text { base } \\
\text { mean } \\
\text { (per- } \\
\text { cent) }\end{array}$ & $\begin{array}{l}\text { Length } \\
\text { (years) }\end{array}$ & $\begin{array}{c}\text { Mean } \\
\text { annual } \\
\text { runoff } \\
\text { (acre- } \\
\mathrm{ft} \text { ) }\end{array}$ & $\begin{array}{c}\text { Median } \\
\text { annual } \\
\text { runoff } \\
\text { (acre - } \\
\mathrm{ft} \text { ) }\end{array}$ & \\
\hline
\end{tabular}

Topanga Creek basin

\begin{tabular}{l|l|r|r|r|r|r|r|r}
\hline $\begin{array}{c}\text { Topanga Creek near } \\
\text { Topanga Beach }\end{array}$ & 17.9 & 7,580 & 423 & +105 & 27 & 3,930 & 1,400 & 3,690 \\
\hline
\end{tabular}

Santa Clara River basin

Santa Clara River at Los Angeles-Ventura County line ${ }^{10}$

Piru Creek above Lake Piru

Piru Creek below Santa Felicia Dam

Hopper Creek near Piru10Sespe Creek near Wheeler Springs _. . . . . . . . . . . Sespe Creek near Fillmore .Santa Paula Creek near Santa Paula

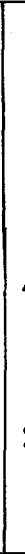

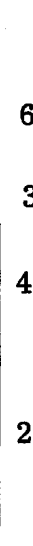

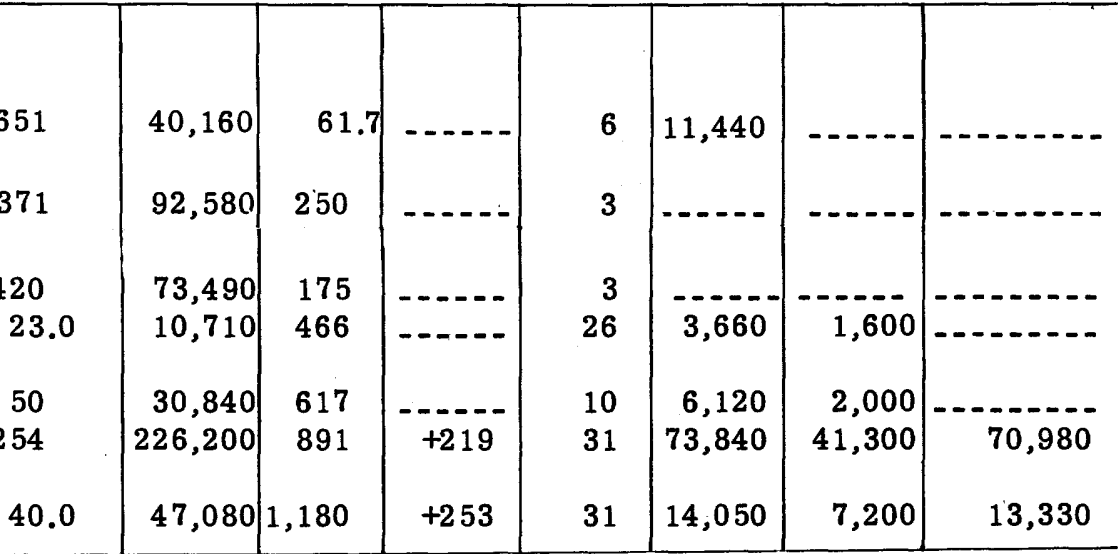

Ventura River basin

\begin{tabular}{|c|c|c|c|c|c|c|c|}
\hline 51 & 67,860 & 1,330 &.---- & 10 & 14,990 & 5,400 & - \\
\hline 55 & 71,780 & 1,310 & +243 & 31 & 22,020 & 10,100 & 20,910 \\
\hline 15.5 & 25,740 & 1,660 & +339 & 29 & 6,680 & 3,000 & 5,860 \\
\hline$-\ldots$ & 23,880 & & $-\ldots$ & 9 & 4,580 & $\ldots$ & $\ldots$ \\
\hline 41.1 & 34,280 & 834 & +298 & 30 & 9,560 & 3,500 & 8,620 \\
\hline 187 & 165,500 & 885 & +255 & 31 & 49,950 & 23,200 & 46,590 \\
\hline
\end{tabular}

Carpinteria Creek basin

\begin{abstract}
Matilija Creek above reservoir, near Matilija Hot Springs .

Matilija Creek at Matilija Hot Springs

North Fork Matilija Creek at Matilija Hot Springs ${ }^{10}$

San Antonio Creek at Casitas Springs ${ }^{10}$

Coyote Creek near Ventura _.

Ventura River near Ventura -
\end{abstract}

.


Table 4. - Runoff for the water year 1957-58-Continued

\begin{tabular}{|c|c|c|c|c|c|c|c|c|}
\hline \multirow[b]{2}{*}{ Stream } & \multirow[b]{2}{*}{$\begin{array}{l}\text { Drain - } \\
\text { age } \\
\text { area } \\
\text { (sq mi) }\end{array}$} & \multicolumn{3}{|c|}{$1957-58$ runoff } & \multicolumn{3}{|c|}{ Period of record } & \multirow{2}{*}{\begin{tabular}{|c} 
Base mean \\
Mean \\
annual \\
runoff \\
$1920-55$ \\
(acre-ft)
\end{tabular}} \\
\hline & & $\begin{array}{c}\text { Acre- } \\
\text { feet }\end{array}$ & $\begin{array}{l}\text { Acre } \\
\text { feet } \\
\text { per } \\
\text { square } \\
\text { mile }\end{array}$ & $\begin{array}{l}\text { Depar- } \\
\text { ture } \\
\text { from } \\
\text { base } \\
\text { mean } \\
\text { (per- } \\
\text { cent) }\end{array}$ & $\begin{array}{l}\text { Length } \\
\text { (years) }\end{array}$ & $\begin{array}{l}\text { Mean } \\
\text { annual } \\
\text { runoff } \\
\text { (acre- } \\
\text { ft) }\end{array}$ & $\begin{array}{c}\text { Median } \\
\text { annual } \\
\text { runoff } \\
\text { (acre - } \\
\mathrm{ft} \text { ) }\end{array}$ & \\
\hline
\end{tabular}

Atascadero Creek basin

\begin{tabular}{|c|c|c|c|c|c|c|c|c|}
\hline $\begin{array}{l}\text { Atascadero Creek near } \\
\text { Goleta }\end{array}$ & 18.3 & 8,440 & 461 & $\ldots$ & 17 & 1,880 & 650 & $\ldots$ \\
\hline
\end{tabular}

San Jose Creek basin

\begin{tabular}{l|r|r|r|r|r|r|r|r}
\hline San Jose Creek near Goleta.- & 5.54 & 4,830 & 872 & $-\ldots .$. & 17 & 1,200 & 650 & $\ldots . . .$. \\
\hline
\end{tabular}

Santa Ynez River basin

\begin{tabular}{|c|}
\hline $\begin{array}{l}\text { Santa Ynez River at Jameson } \\
\text { Lake, near Montecito } 11\end{array}$ \\
\hline Santa Ynez River above \\
\hline Gibraltar Dam, near \\
\hline Santa Barbara ${ }^{12} \ldots$ \\
\hline Santa Ynez River below \\
\hline Gibraltar Dam, near Santa \\
\hline Barbara ${ }^{12}$ \\
\hline Santa Ynez River below Los \\
\hline Laureles Canyon, near Santa \\
\hline Ynez \\
\hline Santa Cruz Creek near Santa \\
\hline Ynez \\
\hline Cachuma Creek near Santa \\
\hline Ynez \\
\hline Santa Ynez River near Santa \\
\hline Ynez \\
\hline Santa Agueda Creek near \\
\hline Santa Ynez . . . . . . \\
\hline Zanja Cota near Santa Ynez. \\
\hline Santa Ynez River at Grand \\
\hline Avenue, near Santa Ynez... \\
\hline Santa Ynez River at Solvang - _- \\
\hline Santa Ynez River at Buellton_. \\
\hline La Zaca Creek at Buellton ... \\
\hline Santa Ynez River near \\
\hline Buellton \\
\hline Santa Ynez River at Santa Rosa \\
\hline Damsite, near Buellton....- \\
\hline Santa Ynez River at Cooper's \\
\hline $\begin{array}{l}\text { Reef, near Lompoc. } \\
\text { Santa Ynez River below Santa }\end{array}$ \\
\hline $\begin{array}{l}\text { Santa Ynez River below Santa } \\
\text { Rita Creek, near Lompoc }\end{array}$ \\
\hline $\begin{array}{l}\text { Salsipuedes Creek near } \\
\text { Lompoc }\end{array}$ \\
\hline
\end{tabular}

See footnotes at end of table.

\begin{tabular}{|c|c|c|c|c|c|c|c|}
\hline 13.8 & 13,440 & 974 & +250 & 27 & 4,430 & 1,700 & 3,840 \\
\hline 216 & 130,670 & 605 & +328 & 38 & 32,000 & 11,500 & 30,540 \\
\hline 216 & 123,600 & 572 & $-\cdots$ & 38 & 27,730 & 8,000 & 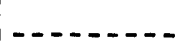 \\
\hline 277 & 164,800 & 595 & $\ldots$ & 11 & 29,390 & 1,900 & מים \\
\hline 73.8 & 43,720 & 592 & $\ldots$ & 16 & 9,340 & 4,900 & $-\ldots$ \\
\hline 20.5 & 11,660 & 569 & $\ldots$ & 8 & 3,170 & $-\ldots$ & $n^{-1-2}$ \\
\hline 422 & 44,000 & 104 & $-\cdots$ & 28 & 60,550 & 14,500 & - \\
\hline 55.9 & 10,690 & 191 & $-\ldots$ & 17 & 2,120 & 720 & - - - \\
\hline 13.4 & 3,090 & 231 & $\ldots$ & 4 & $\ldots$ & $\ldots-\ldots$ & $\ldots$ \\
\hline 513 & 64,460 & 126 & $\ldots$ & 4 & $\ldots$ & $----\cdots$ & - n \\
\hline 579 & 91,640 & 158 & $\ldots$ & 20 & 32,840 & 10,000 & - \\
\hline 594 & 107,700 & 181 & $\ldots$ & 4 & $\ldots$ & - & . \\
\hline 39.5 & 2,320 & 58.7 & $\ldots$ & 17 & $30 \dot{4}$ & 29 & $-\ldots$ \\
\hline 668 & 123,700 & 185 & $-\cdots$ & 6 & 27,610 & 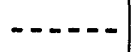 & 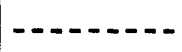 \\
\hline 748 & 122,900 & 164 & $-\ldots-$ & 4 & 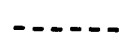 & ----- & 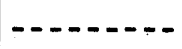 \\
\hline 755 & 117,800 & 156 & 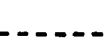 & 4 & $-\cdots$ & - & - \\
\hline 781 & 105,600 & 135 & $\ldots$ & 4 & $\cdots$ & $\cdots-\cdots$ & - \\
\hline 47.0 & 23,560 & 501 & & 17 & 6,140 & 2,200 & - \\
\hline
\end{tabular}


Table 4.-Runoff for the water year 1957-58-Continued

\begin{tabular}{|c|c|c|c|c|c|c|c|c|}
\hline \multirow[b]{2}{*}{ Stream } & \multirow[b]{2}{*}{$\begin{array}{l}\text { Drain- } \\
\text { age } \\
\text { area } \\
\text { (sq } \mathrm{mi})\end{array}$} & \multicolumn{3}{|c|}{$1957-58$ runoff } & \multicolumn{3}{|c|}{ Period of record } & Base mean \\
\hline & & $\begin{array}{c}\text { Acre- } \\
\text { feet }\end{array}$ & $\begin{array}{l}\text { Acre- } \\
\text { feet } \\
\text { per } \\
\text { square } \\
\text { mile }\end{array}$ & $\begin{array}{c}\text { Depar- } \\
\text { ture } \\
\text { from } \\
\text { base } \\
\text { mean } \\
\text { (per- } \\
\text { cent) }\end{array}$ & $\begin{array}{l}\text { Length } \\
\text { (years) }\end{array}$ & $\begin{array}{c}\text { Mean } \\
\text { annual } \\
\text { runoff } \\
\text { (acre- } \\
\text { ft) }\end{array}$ & $\begin{array}{c}\text { Median } \\
\text { annual } \\
\text { runoff } \\
\text { (acre- } \\
\text { ft) }\end{array}$ & $\begin{array}{c}\text { Mean } \\
\text { annual } \\
\text { runoff } \\
1920-55 \\
\text { (acre-ft) }\end{array}$ \\
\hline
\end{tabular}

Santa Ynez River basin-Continued

\begin{tabular}{|c|c|c|c|c|c|c|c|c|}
\hline $\begin{array}{l}\text { Santa Ynez River at Narrows, } \\
\text { near Lompoc } \\
\text { Santa Ynez River near }\end{array}$ & 790 & 140,000 & 177 & $-\cdots$ & 6 & 34,790 & ----- & $\cdots$ \\
\hline Lompoc_. & 790 & 140,200 & 177 & & 33 & 85,060 & 30,900 & \\
\hline $\begin{array}{l}\text { Santa Ynez River at H Street, } \\
\text { near Lompoc } \\
\text { Santa Ynez River at } 13 \text { th }\end{array}$ & 816 & 131,320 & 161 & & 11 & 39,750 & 1,600 & \\
\hline Street, near Lompoc & 820 & 128,500 & 157 & & 4 & $\cdots-1$ & ---- & $\cdots-\cdots-1$ \\
\hline near Surf & 895 & 124,200 & 139 & ---- & 11 & 42,700 & 1,800 & \\
\hline
\end{tabular}

San Antonio Creek basin

\begin{tabular}{l}
$\begin{array}{l}\text { San Antonio Creek near } \\
\text { Casmalia . }\end{array}$ \\
\hline
\end{tabular}

Santa Maria River basin

\begin{tabular}{|c|c|c|c|c|c|c|c|c|}
\hline $\begin{array}{l}\text { Cuyama River near } \\
\text { Ventucopa }\end{array}$ & 90.0 & 26,510 & 295 & $-\cdots$ & 13 & 5,490 & 2,800 & - \\
\hline Cuyama River near Santa & & & & & & & & 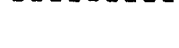 \\
\hline $\begin{array}{l}\text { Maria } \\
\text { Alamo Creek near Santa }\end{array}$ & 912 & 51,520 & 56.5 & +269 & 28 & 15,570 & 7,200 & 13,970 \\
\hline $\begin{array}{l}\text { Maria } \\
\text { Huasna River near Santa }\end{array}$ & 87.7 & 28,600 & 326 & $-\cdots---$ & 15 & 4,750 & 1,700 & 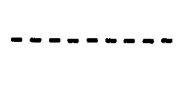 \\
\hline Maria & 119 & 48,940 & 411 & +290 & 28 & 14,620 & 5,500 & 12,540 \\
\hline $\begin{array}{l}\text { Sisquoc River near Sisquoc_- } \\
\text { La Brea Creek near Sisquoc_- }\end{array}$ & $\begin{array}{l}290 \\
86.7\end{array}$ & $\begin{array}{r}110,600 \\
19,200\end{array}$ & $\begin{array}{l}381 \\
221\end{array}$ & & $\begin{array}{l}15 \\
15\end{array}$ & 22,520 & $\begin{array}{r}10,900 \\
580\end{array}$ & 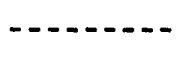 \\
\hline $\begin{array}{l}\text { Tepusquet Creek near } \\
\text { Sisquoc }\end{array}$ & 28.9 & 10,200 & 241 & & 15 & 3,720 & 580 & --- \\
\hline $\begin{array}{l}\text { Sisquoc River near Garey } \\
\text { Santa Maria River at }\end{array}$ & ----- & 99,210 & 100 & (n- & $\begin{array}{l}15 \\
17\end{array}$ & 20,340 & 6,700 & - \\
\hline Guadalupe & 1,763 & 133,500 & 75.7 & $-\cdots-\cdot$ & 17 & 20,710 & 2,200 & 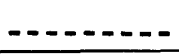 \\
\hline \multicolumn{9}{|c|}{ Arroyo Grande basin } \\
\hline $\begin{array}{l}\text { Arroyo Grande at Arroyo } \\
\text { Grande }\end{array}$ & 106 & 46,750 & 441 & +213 & 18 & 17,090 & 8,000 & 14,940 \\
\hline
\end{tabular}


Table 4.-Runoff for the water year 1957-58-Continued

\begin{tabular}{|c|c|c|c|c|c|c|c|c|}
\hline \multirow[b]{2}{*}{ Stream } & \multirow[b]{2}{*}{$\begin{array}{l}\text { Drain- } \\
\text { age } \\
\text { area } \\
\text { (sq } \mathrm{mi})\end{array}$} & \multicolumn{3}{|c|}{$1957-58$ runoff } & \multicolumn{3}{|c|}{ Period of record } & Base mean \\
\hline & & $\begin{array}{c}\text { Acre- } \\
\text { feet }\end{array}$ & $\begin{array}{c}\text { Acre } \\
\text { feet } \\
\text { per } \\
\text { square } \\
\text { mile }\end{array}$ & $\begin{array}{c}\text { Depar- } \\
\text { ture } \\
\text { from } \\
\text { base } \\
\text { mean } \\
\text { (per- } \\
\text { cent }\end{array}$ & $\begin{array}{l}\text { Length } \\
\text { (years) }\end{array}$ & $\begin{array}{c}\text { Mean } \\
\text { annual } \\
\text { runoff } \\
\text { (acre- } \\
\text { ft) }\end{array}$ & $\begin{array}{l}\text { Median } \\
\text { annual } \\
\text { runoff } \\
\text { (acre- } \\
\text { ft) }\end{array}$ & $\begin{array}{l}\text { Mean } \\
\text { annual } \\
\text { runoff } \\
1920-55 \\
\text { (acre-ft) }\end{array}$ \\
\hline
\end{tabular}

THE GREAT BASIN

Salton Sea basin

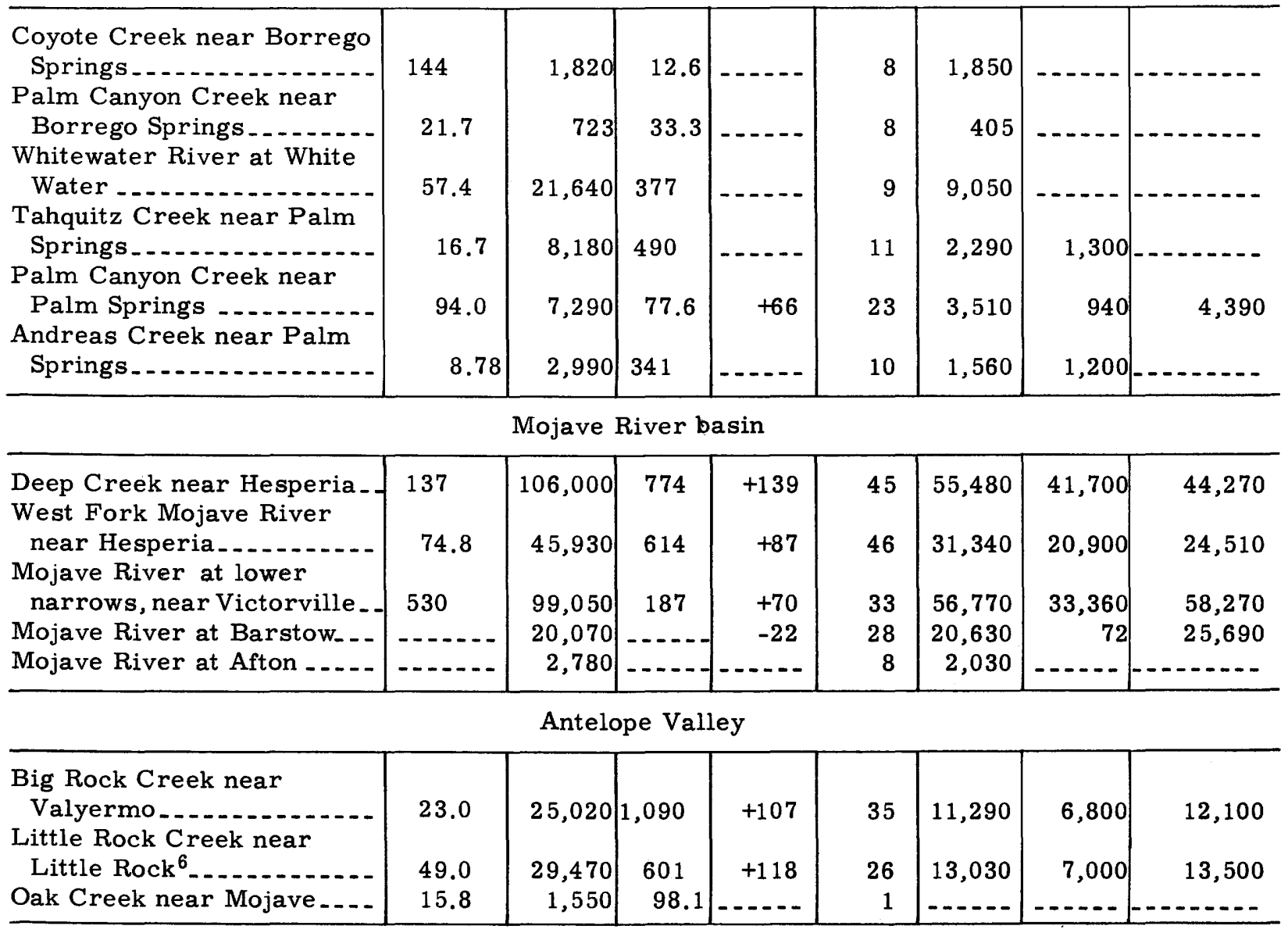

${ }^{1}$ Basic data furnished by the city of San Diego.

${ }^{2}$ Basic data furnished by the California Water and Telephone Co.

${ }^{3}$ Basic data furnished by the Helix Irrigation District.

${ }^{4}$ Basic data furnished by the Vista Irrigation District.

${ }^{5}$ Records furnished by the Orange County Flood Control District.

${ }^{6}$ Records furnished by the Los Angeles County Flood Control District.

${ }^{7}$ Includes about 28,000 acre-ft of water imported from the Colorado River.

8 Adjusted for 92 acre-ft of water imported from the Owens River.

${ }^{9}$ Includes about 63,000 acre-ft of water imported from the Colorado River.

${ }^{10}$ Records furnished by the Ventura County Water Resources Division.

${ }^{11}$ Basic data furnished by the Montecite County Water District.

${ }^{12}$ Basic data furnished by the city of Santa Barbara. 


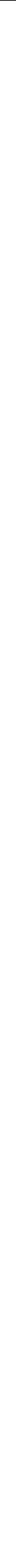

